\title{
Long term change in chemical properties of preindustrial charcoal particles aged in forest and agricultural temperate soil
}

\author{
Brieuc Hardy ${ }^{\mathrm{a}, *}$, Jens Leifeld ${ }^{\mathrm{b}}$, Heike Knicker ${ }^{\mathrm{c}}$, Joseph E. Dufey ${ }^{\mathrm{a}}$, Koen Deforce ${ }^{\mathrm{d}}$, Jean-Thomas Cornélis ${ }^{\mathrm{e}}$ \\ ${ }^{a}$ Earth and Life Institute - Environmental Sciences, Université catholique de Louvain, 1348 Louvain-la-Neuve, Belgium \\ ${ }^{\mathrm{b}}$ Institute for Sustainability Sciences, Agroscope, $\mathrm{CH}-8046$ Zürich, Switzerland \\ 'Instituto de Recursos Naturales y Agrobiología de Sevilla (IRNAS-CSIC), E-41012 Sevilla, Spain \\ ${ }^{\mathrm{d}}$ Directorate Earth and History of Life, Royal Belgian Institute of Natural Sciences, B-1000 Brussels, Belgium \\ ${ }^{\mathrm{e}}$ Department Biosystem Engineering (BIOSE), Gembloux Agro-Bio Tech (GXABT), University of Liège (ULg), 5030 Gembloux, Belgium
}

\section{A R T I C L E I N F O}

\section{Article history:}

Received 22 August 2016

Received in revised form 15 February 2017

Accepted 22 February 2017

Available online 7 March 2017

\section{Keywords:}

Preindustrial charcoal kiln

Land-use change

Biochar

X-ray photoelectron spectroscopy (XPS)

Differential scanning calorimetry (DSC)

Fourier Transform Infrared Spectroscopy

(FTIR)

${ }^{13} \mathrm{C}$ nuclear magnetic resonance $\left({ }^{13} \mathrm{C}\right.$ NMR $)$

Dichromate oxidation

\begin{abstract}
A B S T R A C T
Black carbon (BC) plays an important role in terrestrial carbon storage. Nevertheless, the effect of cultivation on long term dynamics of $B C$ in soil has been poorly addressed. To fill this gap, we studied the chemical properties of charcoal particles extracted from preindustrial kilns in Wallonia, Belgium, along a chronosequence of land use change from forest to agricultural soil, up to 200 years of cultivation. Preindustrial charcoal samples were compared with charcoal subjected to short term ageing in a currently active kiln.

Cultivation increased the association of charcoal with soil minerals, which is favored by deprotonation of carboxylic acids under liming, thereby enhancing the reactivity of charcoal toward mineral surfaces. The large specific surface area of charcoal, related to its porosity, promotes the precipitation of 2:1 phyllosilicates and $\mathrm{CaCO}_{3}$. Both ageing and cultivation decreased the resistance of charcoal to dichromate oxidation, related to an increase in the $\mathrm{H} / \mathrm{C}$ of charcoal. Differential scanning calorimetry revealed the presence of three fractions of distinct thermal stability. Saturation of carboxylate groups with $\mathrm{Ca}^{2+}$ under liming decreased the thermal stability of the O-rich, less thermally stable fraction of charcoal. This fraction decreased over time of cultivation, leading to a relative accumulation of the thermally most stable fraction of charcoal. This might result from the preferential loss of the O-rich fraction or the slowdown of charcoal from oxidation via association with minerals. Our results highlight the idea that land use significantly affects the properties of BC through the modification of soil conditions, which might influence the kinetics of BC loss from soil.
\end{abstract}

(c) 2017 Elsevier Ltd. All rights reserved.

\section{Introduction}

Black carbon (BC), the solid residue of thermal decomposition of biomass, is ubiquitous in soil and sediments (Schmidt and Noack, 2000). According to recent estimates, soil stores ca. $200 \mathrm{Pg}$ of BC in the uppermost $2 \mathrm{~m}$ (Reisser et al., 2016), which corresponds to ca. $10 \%$ of global soil organic carbon (SOC) stocks calculated by Batjes (2016). BC promotes the long-lasting fertility of Amazonian dark earths (Glaser and Birk, 2012) and contributes to long term soil $C$ storage because it is more resistant to degradation than uncharred soil organic matter (SOM). Hence, soil amendment with biochar (BC produced intentionally to be applied to soil) is increasingly being regarded as a feasible alternative to tackling

\footnotetext{
* Corresponding author.

E-mail address: brieuc.hardy@uclouvain.be (B. Hardy).
}

greenhouse gas emissions by increasing soil carbon sequestration, while enhancing sustainably soil fertility (Lehmann, 2007).

Despite the general agreement that $\mathrm{BC}$ lasts longer in soil than uncharred OM, its stability and persistence in soil is still debated. On one hand, the presence of $\mathrm{BC}$ in geological records since the Devonian and of millennial BC in a range of soils at global scale provides evidence that some persists for a very long time in the environment (Schmidt and Noack, 2000). On the other hand, the content of BC stored in soil is low with respect to annual production rate from wildfires, which demonstrates that large amounts are lost from soil (Schmidt and Noack, 2000; Masiello, 2004; Schmidt, 2004), possibly by microbial decomposition (Baldock and Smernik, 2002; Hamer et al., 2004; Wengel et al., 2006), erosion (Rumpel et al., 2006) or dissolution and transport with water fluxes (Hockaday et al., 2007; Jaffé et al., 2013). The longevity of $\mathrm{BC}$ in soil seems to depend on both intrinsic quality and the environmental conditions where it is deposited (Bird 
et al., 2015). Feedstock and conditions of production control the degradation potential of $\mathrm{BC}$, with a main role for the maximum temperature of pyrolysis that controls the degree of condensation of aromatic clusters (Keiluweit et al., 2010; Wiedemeier et al., 2015).

Once deposited in the environment, $\mathrm{BC}$ is subject to a range of reactions. Ageing consists mainly of oxidation of exposed $C$ rings with a high density of $\pi$ electrons and free radicals (Joseph et al., 2010), which creates a high density of O-rich functional groups at the $\mathrm{BC}$ surface. Oxidation starts at the surface and propagates to the core of particles over time (Lehmann et al., 2005), promoting further physical, chemical and microbial degradation (Hammes and Schmidt, 2009). The drivers of oxidation can be biotic (Hamer et al., 2004; Wengel et al., 2006) but are mainly abiotic, at least shortly after introduction to soil (Cheng et al., 2006). The adsorption of dissolved organic compounds can contribute to the increase in O content at the surface of BC (Lehmann et al., 2005). Climatic factors such as water regime (Nguyen and Lehmann, 2009) and temperature were shown to influence the kinetics of alteration and decomposition of BC (Cheng et al., 2008b; Nguyen et al., 2010). Soil conditions are also expected to have an influence. For instance, preferential accumulation of BC was observed in clayrich soils (Reisser et al., 2016), which suggests that association with minerals might be an important mechanism of its stabilization in soil (Czimczik and Masiello, 2007).

In the last decade, much effort has been made to characterize the short term effects of various types of biochar after addition to soil, to design biochar with a high persistence in soil and favorable agronomic properties (Abiven et al., 2014). Nevertheless, properties are known to change over time (Joseph et al., 2010) and mid-term to long term dynamics in soil have been poorly addressed due to the lack of long term experiments. Amazonian dark earths, which triggered interest in biochar, probably comprise the best documented long term case study of BC in soil. Nevertheless, results from terra preta are difficult to extrapolate to other soil, climatic and agronomic contexts. In particular, the dynamics of BC ageing under intensive cultivation have been disregarded. As soil amendment with biochar targets mainly agricultural soils, a better assessment of the effect of cultivation on BC properties is crucial for predicting the long term dynamics of biochar and BC in soil.

Recently, Hardy et al. (2017) characterized the effect of preindustrial charcoal kiln sites on the chemical properties of agricultural soils from Wallonia, Belgium. On bare soil, the sites appear as black spots a few decameters in diameter, with the topsoil largely enriched with charcoal residues (Kerré et al., 2016; Hardy et al., 2017). Traditional charcoal production occurred in the forest, but part of the land was cleared for cultivation from the early 19th century. The presence of charcoal kiln sites in agricultural soils provides the opportunity to investigate how cultivation affects the dynamics of charcoal ageing, by comparison with sites from the same episode of charcoal production that remained forested since the time of charcoal production.

Nguyen et al. (2008) studied the evolution of properties of BC particles over time in agricultural soils in Kenya cleared from forest by fire. They highlighted that association of charcoal with soil minerals increases over time. They also showed that the content of BC in soil decreased sharply during the first $20 \mathrm{yr}$ after clearing but remained similar after that. As the decrease in BC loss correlated with the increase in association with soil minerals, they suggested that organo-mineral association might be an important mechanism in the stabilization of BC. Nevertheless, Nguyen et al. (2008) studied BC dynamics over time in agricultural soil, which does not allow distinguishing between the effect of time and of cultivation on BC properties. By selecting kiln sites abandoned at the same time and converted to agricultural land at different times, we aimed to discriminate between the effect of time and of cultivation on the organic and inorganic composition and stability of charcoal particles aged in soil. We assumed that cultivation might accelerate the physical, chemical and biological weathering of charcoal by way of the mechanical action of tillage and the improved soil fertility related to liming and the use of organic and inorganic fertilizers. Properties of preindustrial charcoals were also compared with those of charcoal from a currently active kiln site, used as a reference with limited ageing.

\section{Material and methods}

\subsection{Study sites and sampling}

On bare soil, preindustrial charcoal kiln sites are easily detected in the field or from interpretation of high spatial resolution aerial photographs and satellite imagery based on their black color (Hardy et al., 2017). We sought agricultural fields containing charcoal kiln sites in cultivated areas deforested since the time of charcoal production, based on a map of mutations of the Walloon forest since 1777 (Kervyn et al., 2014). In these areas, mean annual precipitation varies from 864 to $1145 \mathrm{~mm}$ and mean annual temperature from 9.2 to $10.0^{\circ} \mathrm{C}$. We selected fields affected by charcoal production exclusively on Haplic Luvisols developed in quaternary loess, which is a homogeneous substrate. Accordingly, intrinsic soil properties (texture, mineralogy ...) that can affect the kinetics of charcoal ageing were similar for all sites.

We identified different episodes of land use change from forest to cropland thanks to a number of historical maps. For early deforestation, we referred to the map of Ferraris (1770-1778), that of Vandermaelen (1846-1854), that of the "dépôt de la guerre" (1864-1872) and those of the "Institut de Cartographie Militaire" that include several mapping campaigns between 1878 and 1940. For more recent cultivation time steps, we referred to several maps of the national geographic institute, completed by interviews of farmers. In total, 8 plots were chosen for sampling, with 6 different cultivation times from 2 to ca. $200 \mathrm{yr}$ cropping (Table 1). For time zero of cultivation, we chose a plot that had remained in grassland after deforestation. Historical maps allowed us to define a minimal and maximal age of land use change from forest to cropland, but not an accurate time of deforestation. Therefore, for further data analysis, we attributed to each field the mean value of the range of possible cultivation time, assuming that fields were cropped continuously thereafter (Table 1 ). In spite of the uncertainty about the exact time of cultivation, the total organic carbon (TOC) content of the soil adjacent to the kiln sites, unaffected by charcoal production, decreased progressively with mean cultivation time as estimated from historical maps. This supports the idea that we had correctly identified a chronosequence of cultivation (Fig. A1), as conversion of land from forest to cropland decreases soil C stock (e.g. Nye and Greenland, 1964; Guo and Gifford, 2002; Goidts and van Wesemael, 2007; Solomon et al., 2007). Soils were sampled in November 2014. For each field, we sampled the topsoil $(0-30 \mathrm{~cm})$ from 3 charcoal kiln sites with a gouge auger $3 \mathrm{~cm}$ in diameter. Each sample was bulked from 20 cores from the center of the kiln site.

For comparison with charcoal aged in forest soil (never converted to cropland since the last production of charcoal) we refer to four sites on Luvisols from the weathering of quaternary loess described and characterized by Hardy et al. (2016). The sites are the forest equivalent of those deforested for cultivation. We also refer to the topsoil of a currently active charcoal kiln close to Dole (France) and characterized previously (Hardy et al., 2016), as a reference subjected to limited ageing (the site was sampled 6 months after the last pyrolysis). Except for the currently active kiln, the 
Table 1

Coordinates, land use type and years of cultivation at time of sampling.

\begin{tabular}{|c|c|c|c|c|}
\hline Land use & Lat. $\mathrm{N}\left({ }^{\circ}\right)$ & Long. $\mathrm{E}\left({ }^{\circ}\right)$ & Time of cultivation (yr) & Dominant feedstock ${ }^{\mathrm{a}}$ \\
\hline Forest & - & - & 0 & Quercus sp., Carpinus betulus L., Corylus avellana L., Betula sp. \\
\hline Grassland & 49.996 & 4.209 & 0 & Carpinus betulus L., Quercus sp., Fagus sylvatica L., Betula sp. \\
\hline Cropland & 49.997 & 4.213 & 2 & Carpinus betulus L., Quercus sp., Fagus sylvatica L. \\
\hline Cropland & 50.002 & 4.207 & 23 & Carpinus betulus L., Quercus sp., Betula sp. \\
\hline Cropland & 4.995 & 4.201 & 23 & Quercus sp., Carpinus betulus L., Fagus sylvatica L., Betula sp. \\
\hline Cropland & 50.534 & 4.761 & 130 & Quercus sp., Corylus avellana L., Carpinus betulus L. \\
\hline Cropland & 50.541 & 4.764 & 155 & Quercus sp., Corylus avellana L., Alnus sp. \\
\hline Cropland & 50.521 & 4.755 & 200 & Carpinus betulus L., Corylus avellana L. \\
\hline Cropland & 50.588 & 4.509 & 200 & Carpinus betulus L., Corylus avellana L., Betula sp. \\
\hline
\end{tabular}

a Refers to wood species identified from microscopic observation of randomly chosen charcoal particles.

sites here result from the same episode of charcoal production, related to preindustrial iron smelting and steel making (Hardy et al., 2016). It is likely that they date to the late 18th century, when charcoal production reached a peak in Wallonia. At that time, $75 \%$ of available wood resources were necessary to supply the charcoal needed for smelting activity (Hardy and Dufey, 2012). Charcoal production virtually ceased in the early 19th century, when coke replaced charcoal as an industrial fuel in iron metallurgy, and had stopped by 1860 (Evrard, 1956). Therefore, we assumed that our sites were active in the same time period, making land use the main discriminatory variable impacting on the evolution of soil and charcoal properties at the kiln sites over time. More precise radiocarbon dating of charcoal is complicated because of the 'Suess-effect', which makes it difficult to discriminate between ages younger than 1650 AD (Reimer, 2013).

It is important to note that the change of land use from forest to cropland, frequently referred to in the text as "cultivation", consists of a whole system change that involves (i) tillage, (ii) the frequent application of organic and inorganic fertilizers, liming amendment, and herbicides and pesticides and (iii) a shift in the quality and quantity of SOM inputs due to the shift from forest vegetation to field crops and the export of biomass through harvesting. The present study did not aim to test individually the different factors related to this system change.

\subsection{Soil properties}

A subsample of each soil was gently ground and sieved to $2 \mathrm{~mm}$ for physico-chemical characterization. The $\mathrm{pH}$ was measured in water $\left(\mathrm{pH}_{\mathrm{H} 2 \mathrm{O}}\right)$, with a 1:5 soil:water ratio. Texture was determined by sedimentation (Day, 1965) on ca. $10 \mathrm{~g}$ soil pretreated with $2.5 \mathrm{M}$ $\mathrm{HCl}$ and $30 \% \mathrm{H}_{2} \mathrm{O}_{2}$ to remove carbonate and SOM, respectively (AFNOR X31-107). Total C content was measured by way of dry combustion with a Vario MAX (ㄷ Elementar, Earth and Life Institute, Louvain-la-Neuve, Belgium) elemental analyzer. Inorganic C content was determined with the modified pressure calcimeter method (Sherrod et al., 2002) on finely ground subsamples (< $200 \mu \mathrm{m})$. SOC content was calculated by difference between total and inorganic $C$ content.

\subsection{Separation of charcoal particles and identification of wood species}

Charcoal particles $>1 \mathrm{~mm}$ were separated from soil using wet sieving. The residue, containing charcoal particles, was rinsed abundantly with demineralized water and air dried. Charcoal pieces were separated from inorganic material by flotation in water and then rinsed again several times with demineralized water in a $500 \mathrm{ml}$ beaker, until the water was clear. Plant residues were removed manually from charcoal pieces. Between 50 and $>400$ charcoal pieces were collected for each site.

In the environmental context of the sites, the potential natural forest is dominated by oak (Quercus robur L.), with mainly hornbeam (Carpinus betulus L.) in the understorey (Bohn et al., 2003).
To verify the assumption that these forest species were the dominant feedstock used for charcoal production, randomly selected charcoal fragments $(n=995)$ were identified for at least one kiln site from each plot. The fragments were broken in transversal, radial and tangential planes and studied with an incident light microscope with dark field illumination at 50-500× magnification (Fig. A2). Identification of wood type was based on characteristic anatomical features (Schweingruber, 1990) and comparison with a reference collection of modern charcoal samples. Except for the modern kiln that is dominated by beech (Fagus sylvatica), the charcoal assemblages of all the samples were generally dominated by oak (Quercus sp.) and hornbeam (C. betulus) (Table 1). Beech (F. sylvatica), hazel (Corylus avellana) and birch (Betula sp.) also occurred frequently, whereas maple (Acer sp.), alder (Alnus sp.), dogwood (Cornus sp.), common ash (Fraxinus excelsior), apple subfamily (Maloideae) and willow (Salix sp.) were minor components of the assemblages. The results support that the idea that all preindustrial kilns in this study originated from the exploitation of the same woodland type.

\subsection{Chemical analysis of charcoal particles}

Charcoal particles were ground to a powder with an agate pestle and mortar.

\subsubsection{Elemental composition, loss on ignition}

Elemental composition ( $\mathrm{C}, \mathrm{H}, \mathrm{N}$ and $\mathrm{O}$ ) of charcoal powder was determined with a Euro EA elemental analyzer [HEKAtech $\mathrm{GmbH}$, Germany]. C, $\mathrm{H}$ and $\mathrm{N}$ were measured via dry combustion and $\mathrm{O}$ was analyzed using pyrolysis at $1000^{\circ} \mathrm{C}$. Whereas $\mathrm{N}$ and $\mathrm{H}$ derive exclusively from $\mathrm{OM}, \mathrm{C}$ and $\mathrm{O}$ originate from $\mathrm{OM}$ and carbonate. To differentiate between organic and inorganic $\mathrm{C}$ and $\mathrm{O}$, carbonate content was determined from loss on ignition between 550 and $1000^{\circ} \mathrm{C}$; ca. $100 \mathrm{mg}$ charcoal powder were weighed and dried at $105^{\circ} \mathrm{C}$. The sample was then heated overnight at $550^{\circ} \mathrm{C}$ to oxidize all the $\mathrm{OM}$, and heated again overnight at $1000^{\circ} \mathrm{C}$ to remove carbonate. OM $\left(\Delta 550-105^{\circ} \mathrm{C}\right)$ content and carbonate $(\Delta 1000-$ $550{ }^{\circ} \mathrm{C}$ ) content were determined gravimetrically, and inorganic $\mathrm{C}$ and $\mathrm{O}$ content from carbonate were calculated on the basis of atomic mass. Between the different heating steps, samples were systematically kept in a desiccator. Organic $\mathrm{C}$ and $\mathrm{O}$ were calculated from the difference between elemental and inorganic content. OM content, estimated by summing organic $\mathrm{C}, \mathrm{H}, \mathrm{N}$ and $\mathrm{O}$ content (viz. after retrieving the contribution of carbonate), was consistent with $\mathrm{OM}$ content estimated from loss on ignition $\left(\Delta 550-105^{\circ} \mathrm{C}\right.$; Fig. A3).

\subsubsection{X-ray photoelectron spectroscopy (XPS)}

To quantify total atomic content of major elements (C, O, N, Si, $\mathrm{Al}$, Fe and Ca), charcoal powder was analyzed with a SSX 100/206 photoelectron spectrometer [Surface Science Instruments, USA] equipped with a monochromatized micro focused Al X-ray source powered at $20 \mathrm{~mA}$ and $10 \mathrm{kV}$. Powder was fixed on a stainless steel 
multi-specimen holder with double sided insulating tape. The analysis chamber was around $10^{-6} \mathrm{~Pa}$ and the angle between the surface normal and the axis of the analyzer lens was $55^{\circ}$. The pass energy was $150 \mathrm{eV}$ and the area analyzed was ca. $1.4 \mathrm{~mm}^{2}$. In these conditions, the full width at half maximum (FWHM) of the Au $4 f_{7 / 2}$ peak of a clean Au standard sample is about $1.6 \mathrm{eV}$. A flood gun at $8 \mathrm{eV}$ and a $\mathrm{Ni}$ grid placed $3 \mathrm{~mm}$ above the sample surface were used for charge stabilization (Bryson, 1987). The C-(C, H) component of the $\mathrm{C} 1 \mathrm{~s}$ peak of carbon was fixed at $284.8 \mathrm{eV}$ to calibrate the binding energy scale. Data were analyzed with CasaXPS [Casa Software Ltd., UK]. Atomic fractions were calculated using peak areas after a non-linear background subtraction (Shirley, 1972), based on experimental sensitivity factors and transmission factors provided by the manufacturer.

\subsubsection{Fourier transform infrared spectroscopy (FTIR)}

FTIR spectra of charcoal powder were obtained with a Bruker Equinox 55 FTIR spectrometer ( ${ }^{\odot}$ Bruker, USA), in transmission mode, with single-bounce diamond attenuated total reflection (ATR) equipment and a Trans DTGS detector. One hundred scans were taken for both background and samples, from 4000 to $400 \mathrm{~cm}^{-1}$, with a resolution of $2 \mathrm{~cm}^{-1}$. Spectra were normalized on the basis of maximal deviation. Attribution of organic and inorganic components to bands was based on Lehmann and Solomon (2010) and Biester et al. (2014).

\subsubsection{Cross polarization magic angle spinning- ${ }^{13} \mathrm{C}$ nuclear magnetic resonance spectroscopy (CPMAS- ${ }^{13} \mathrm{C} N M R$ )}

Solid state ${ }^{13} \mathrm{C}$ NMR spectra were obtained with a Bruker Avance III HD $400 \mathrm{MHz}$ Wideboard spectrometer (Bruker, USA) at $100.65 \mathrm{MHz}$ using $\mathrm{Zr}$ rotors of $4 \mathrm{~mm}$ outer diameter with KEL-Fcaps. CPMAS was applied during magic angle spinning of the rotor at $14 \mathrm{kHz}$. A ramped ${ }^{1} \mathrm{H}$ pulse was used to circumvent spin modulation of Hartmann-Hahn conditions. A contact time of $1 \mathrm{~ms}$ and a $90^{\circ}{ }^{1} \mathrm{H}$-pulse width of $2.5 \mu$ s were used. The chemical shifts were calibrated to $0 \mathrm{ppm}$ with tetramethylsilane and to $176.04 \mathrm{ppm}$ with glycine. Pulse delay between single scans were 300 ms. Proportions of different types of $C$ were estimated by integrating signal intensity in the spectra for different chemical shift regions (Knicker, 2011), with MESTRE NOVA software. The region from 0 to $45 \mathrm{ppm}$ was attributed to alkyl-C, from 45 to $110 \mathrm{ppm}$ to Oand N-alkyl and from 160 to 225 ppm to carbonyl-, carboxyland amide-C. For quantification of aryl-C, the spinning side bands ( -50 to $0 \mathrm{ppm}$ and $225-300 \mathrm{ppm}$ ) were added to the signal ranging from 110 to $160 \mathrm{ppm}$.

\subsubsection{Differential scanning calorimetry (DSC)}

Samples were scanned with a DSC Q100 instrument; TA Instruments, USA) after heat flow calibration with sapphire, and temperature and heat calibration with the melting of In (Danley, 2003). Before analysis, all samples were diluted $20 \times$ with $\mathrm{Al}_{2} \mathrm{O}_{3}$ and homogenized in a ball mill. Between 15 and $25 \mathrm{mg}$ charcoal powder were weighed into an open $\mathrm{Al}$ pan. An empty pan served as reference. Samples were heated under a flow of $50 \mathrm{ml} / \mathrm{min}$ synthetic air from room temperature to $600^{\circ} \mathrm{C}$ at $10^{\circ} \mathrm{C} / \mathrm{min}$ (Leifeld, 2007).

Peak temperature $\left({ }^{\circ} \mathrm{C}\right)$, height $(\mathrm{W} / \mathrm{g})$ and area $(\mathrm{J} / \mathrm{g})$ and total heat of reaction $(\mathrm{J} / \mathrm{g})$ were determined from DSC thermograms with Universal Analysis 2000 software (TA Instruments, USA). After identification of a maximum, peak height was measured as the maximum deviation from a linear baseline drawn between 150 and $600{ }^{\circ} \mathrm{C}$. Peak area was obtained by vertical drop between two adjacent peaks based on the position of the minima (Fig. A4). For each parameter, we estimated a 95\% confidence interval from repeated measurements $(n=6)$ on the same sample, which was systematically $<2 \%$ of the measured value.

\subsubsection{Dichromate oxidation}

The oxidizable $\mathrm{C}$ content of charcoal was determined via oxidation with $\mathrm{K}_{2} \mathrm{Cr}_{2} \mathrm{O}_{7}$ according to the original procedure described by Walkley (1947). In brief, $10 \mathrm{ml} 0.167 \mathrm{M} \mathrm{K}_{2} \mathrm{Cr}_{2} \mathrm{O}_{7}$ was poured in a $500 \mathrm{ml}$ Erlenmeyer flask containing between 25 and $50 \mathrm{mg}$ charcoal powder; $20 \mathrm{ml}$ conc. $\mathrm{H}_{2} \mathrm{SO}_{4}$ were added and the mixture shaken for $1 \mathrm{~min}$. After $30 \mathrm{~min}$, reaction was stopped by adding $200 \mathrm{ml}$ demineralized water. Excess of $\mathrm{Cr}_{2} \mathrm{O}_{7}^{2-}$ was titrated with $0.25 \mathrm{M}$ $\mathrm{FeSO}_{4}$ in the presence of concentrated $\mathrm{H}_{3} \mathrm{PO}_{4}, \mathrm{BaCl}_{2}$ and diphenylamine as an indicator.

\section{Results}

\subsection{XPS}

Even though XPS measures the binding energy of core electrons from the surface $(<10 \mathrm{~nm})$ of a sample, we assumed that atomic composition established from the method is representative of the bulk properties of a sample, as charcoal samples finely ground to powder were analyzed (Nguyen et al., 2008). Charcoal contained from $45.1 \%$ to $77.2 \%$ C, $17.4 \%$ to $42.2 \%$ O and $1.34 \%$ to $1.93 \%$ N. It also contained $1.46 \%$ to $6.18 \% \mathrm{Si}, 0.86 \%$ to $3.33 \% \mathrm{Al}, 0.23 \%$ to $1.75 \% \mathrm{Ca}$ and $0.16 \%$ to $1.22 \% \mathrm{Fe}$. Small amounts of $\mathrm{K}$ and $\mathrm{Mg}$ were detected in some samples. Other elements expected to take part in the composition of charcoal, such as $\mathrm{P}, \mathrm{S}$ or $\mathrm{Na}$, were not present in sufficient concentration to yield a signal.

We investigated the relationship between elements present in significant amount in charcoal land-use history (Fig. 1). Total C content decreased largely with both ageing and cultivation time, in contrast to total $\mathrm{O}$, which increased sharply (Fig. 1). Total $\mathrm{N}$ did not appear to be affected by ageing or cultivation. $\mathrm{Si}, \mathrm{Al}$ and Fe all increased sharply with ageing and, overall, cultivation time, whereas Ca decreased with ageing in an acidic forest soil but reincreased sharply with cultivation (Fig. 1).

\subsection{FTIR}

All spectra showed a main peak at ca. $1550 \mathrm{~cm}^{-1}$, corresponding to aromatic $\mathrm{C}=\mathrm{C}$ vibration and stretching (Fig. 2). A smaller signal at ca. $1700 \mathrm{~cm}^{-1}$ corresponds to $\mathrm{C}=\mathrm{O}$ stretching of carboxyl, quinone, amide, ketone, ester or aldehyde (Lehmann and Solomon, 2010). The peak seemed to decrease gradually from forest charcoal to charcoal with the longest cultivation time, like another weak signal at ca. $1230 \mathrm{~cm}^{-1}$ corresponding to $\mathrm{C}-\mathrm{O}$ stretch or to $\mathrm{O}-\mathrm{H}$ bending of $\mathrm{COOH}$ groups (Fig. 2). In contrast, the signal at ca. $1350 \mathrm{~cm}^{-1}$, attributed to $\mathrm{COO}^{-}$, was weaker for charcoal from forest soil than from grassland or cropland soil. A double peak in the $1100-950 \mathrm{~cm}^{-1}$ region, corresponding to $\mathrm{O}-\mathrm{Si}-\mathrm{O}$ stretching, clearly increased over time of cultivation, as well as the peaks in the $550-400 \mathrm{~cm}^{-1}$ region, attributed to $\mathrm{O}-\mathrm{Si}-\mathrm{O}$ stretching or $\mathrm{Fe}-\mathrm{O}$ bending (Fig. 2). The signal from inorganic soil components overlapped with peaks of small intensity corresponding to cellulose, carbohydrate and polysaccharide (at ca. 1200, 1030 and $890 \mathrm{~cm}^{-1}$; Biester et al., 2014).

\subsection{Carbonate}

Carbonate content varied from $0.22 \%$ to $5.73 \%$ in charcoal. It correlated closely with the $\mathrm{pH}$ of the soil from which it was extracted ( $r$ 0.944; Fig. 3a), if data from the active kiln site were removed. Ca content, determined from XPS, appeared to relate closely to carbonate content ( $r$ 0.894; Fig. $3 \mathrm{~b}$ ), supporting the idea that the carbonate was in the form of $\mathrm{CaCO}_{3}$. 
a)

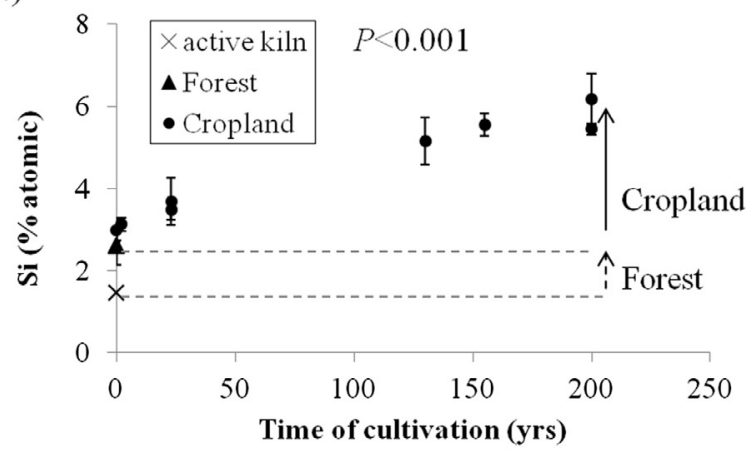

c)

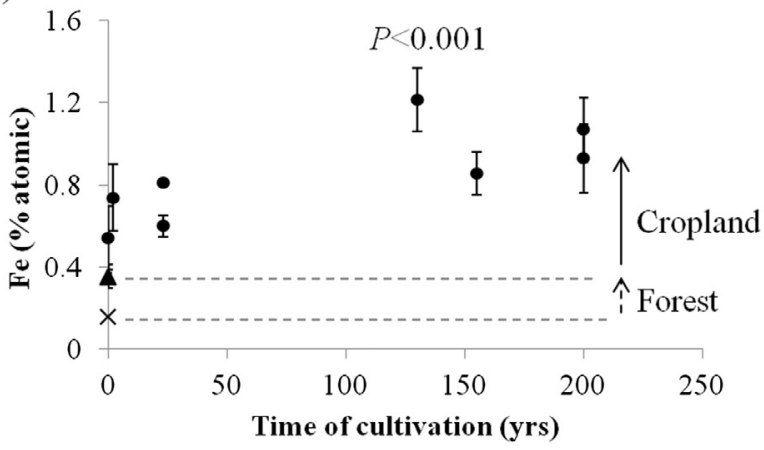

e)

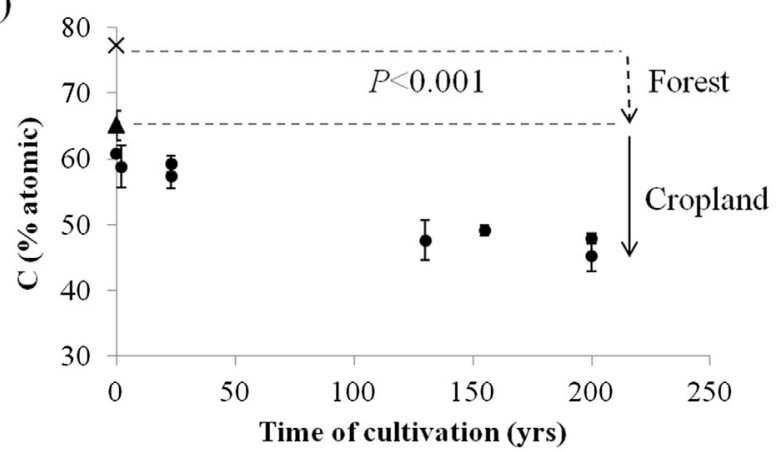

g)

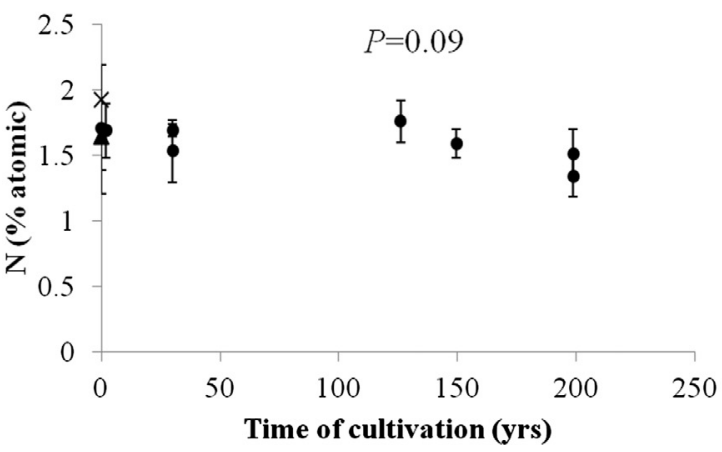

b)

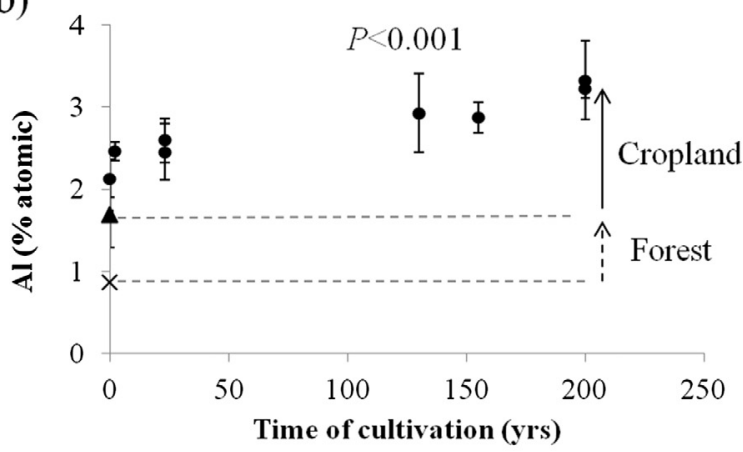

d)

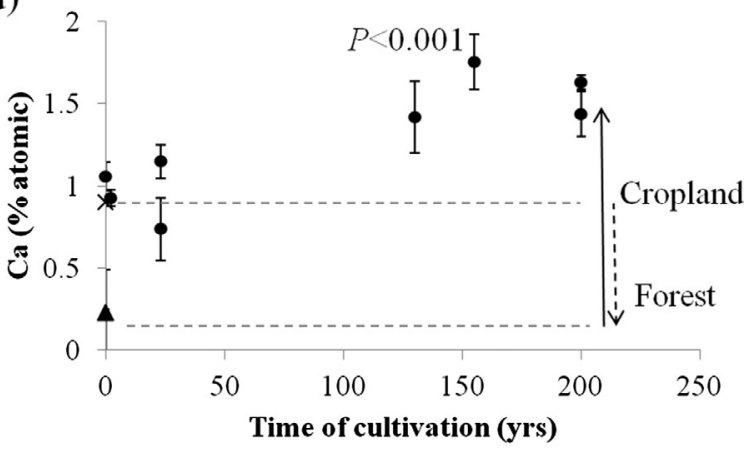

f)

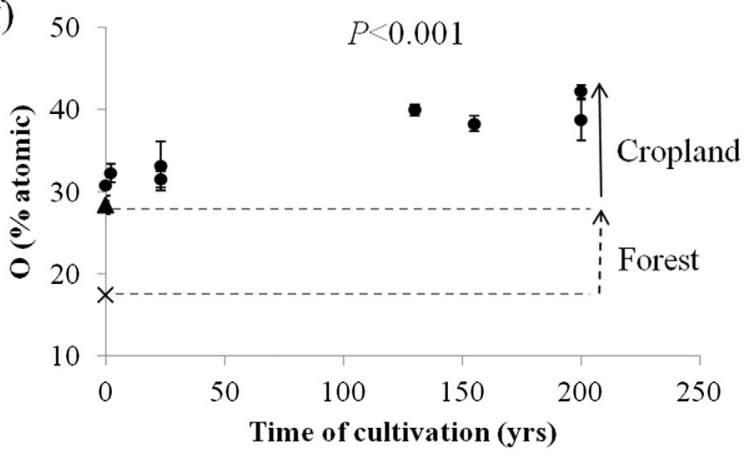

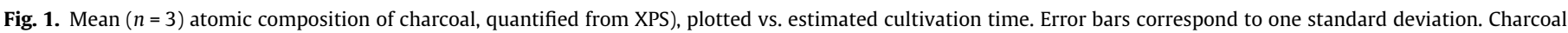

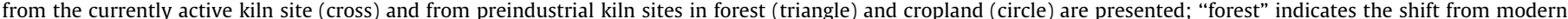

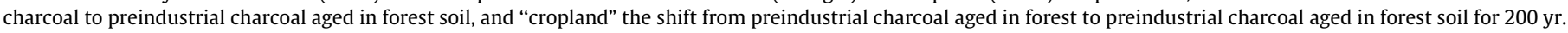
$P$-values were obtained from ANOVA and refer to relationship between variable and time of cultivation (excluding charcoal from the currently active kiln).

\subsection{Organic composition}

Data were plotted in a Van Krevelen diagram (Fig. 4) for atomic $\mathrm{H} / \mathrm{C}$ ratio vs. atomic $\mathrm{O} / \mathrm{C}$ ratio for the organic fraction (after removal of inorganic $\mathrm{C}$ and $\mathrm{O}$ content from carbonate). In relation to the diagram, the charcoals were compared with literature data for biomass heated in the absence of air at various temperature values up to $800^{\circ} \mathrm{C}$, resulting in a range of products from uncharred biomass to biochar with a high degree of aromaticity and aromatic condensation (Keiluweit et al., 2010; Budai et al., 2014). Whereas charcoal 


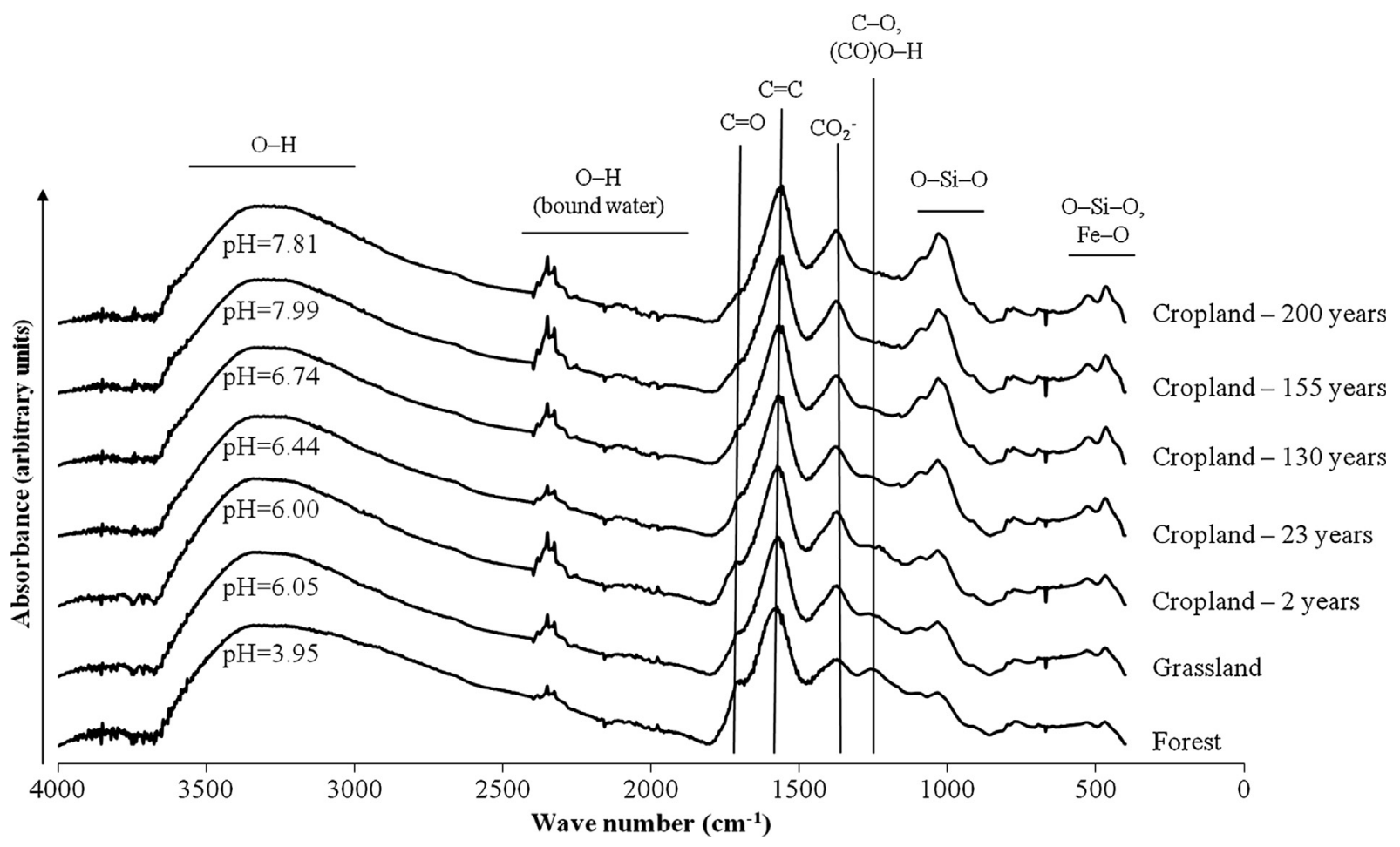

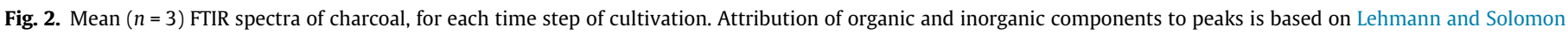
(2010); pH value under each curve corresponds to mean $\mathrm{pH}$ of soil from which charcoal was extracted.
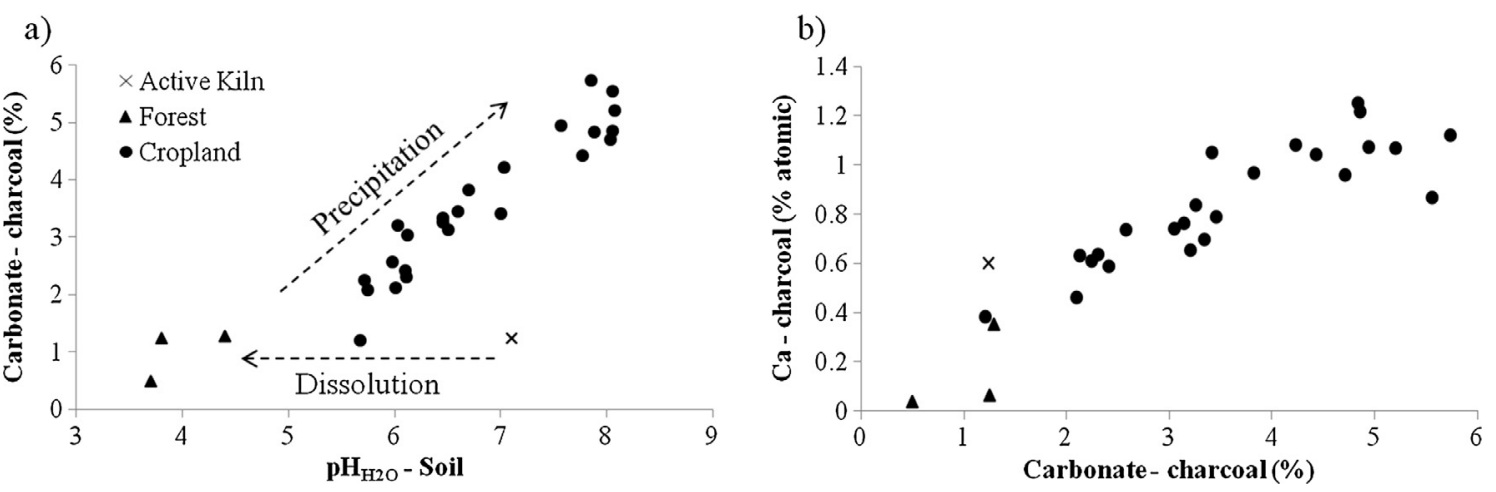

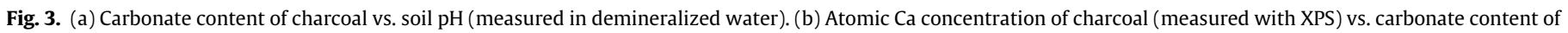
charcoal.

from the active kiln site had $\mathrm{H} / \mathrm{C} 0.30$ and $\mathrm{O} / \mathrm{C} 0.11$ (Fig. 4), preindustrial charcoal samples had $\mathrm{H} / \mathrm{C}$ ranging from 0.57 to 0.77 and $\mathrm{O} /$ $\mathrm{C}$ ranging from 0.34 to 0.43 . $\mathrm{H} / \mathrm{C}$ and $\mathrm{O} / \mathrm{C}$ for preindustrial charcoals correlated positively ( $r$ 0.58).

$\mathrm{OC}$ and organic $\mathrm{O}$ content, as well as organic $\mathrm{H} / \mathrm{C}$ and $\mathrm{O} / \mathrm{C}$ ratios were also plotted vs. time of cultivation (Fig. 5). OC followed the same trend as for total $C$ from XPS, consisting of a sharp decrease from ageing in a forest soil and a continued decrease over time of cultivation. Organic $\mathrm{O}$, however, evolved differently from total $\mathrm{O}$ with time of cultivation: it increased largely with ageing but decreased clearly with time of cultivation (Fig. 5). Both organic $\mathrm{H} / \mathrm{C}$ and $\mathrm{O} / \mathrm{C}$ increased with ageing (Fig. 5), as observed on the Van Krevelen diagram (Fig. 4). Their evolution with time of cultivation was not clear; however, if we excluded forest charcoal samples, both organic $\mathrm{H} / \mathrm{C}$ and $\mathrm{O} / \mathrm{C}$ appeared to decrease slightly vs. time of cultivation ( $r-0.44$ and $r-0.57$, respectively).

\subsection{CPMAS- ${ }^{13} \mathrm{C} N M R$}

Proportions of different types of $\mathrm{C}$ in charcoal were estimated (Fig. 6) for a selection of preindustrial charcoals (one per plot) from integration of chemical shift regions in the spectra, according to Knicker (2011). All preindustrial charcoals had a comparable signature, comprising mainly aromatic C ranging from $73.4 \%$ to $79.5 \%$ (Fig. 6). They also contained $4.35-8.70 \%$ alkyl-C, $7.8-11.3 \%$ O- and N-alkyl and 6.6-8.0\% carboxyl, carbonyl or amide-C. All signatures were comparable, with no clear effect of cultivation time.

\subsection{DSC}

DSC thermograms showed three easily detectable local maxima - peak 1, peak 2 and peak 3 - corresponding to three levels of increasing thermal stability (Fig. 7a). The temperature for peak 1 


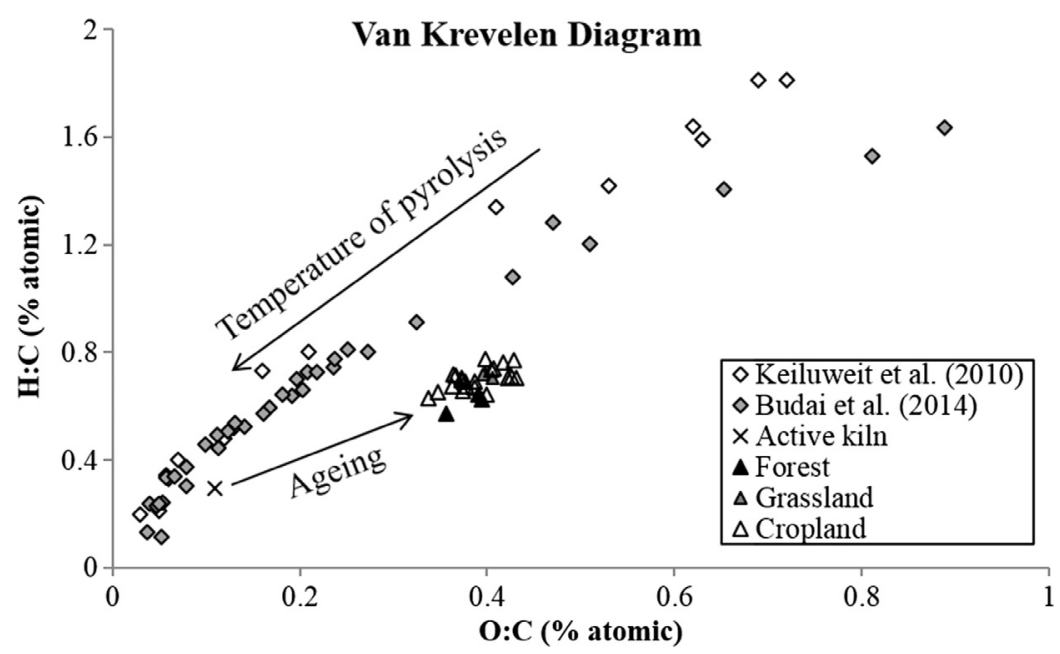

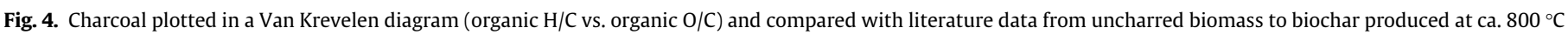
(Keiluweit et al., 2010; Budai et al., 2014).

a)

80

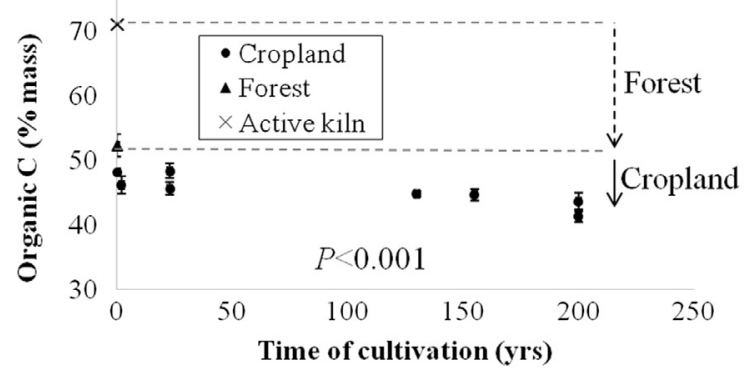

c)

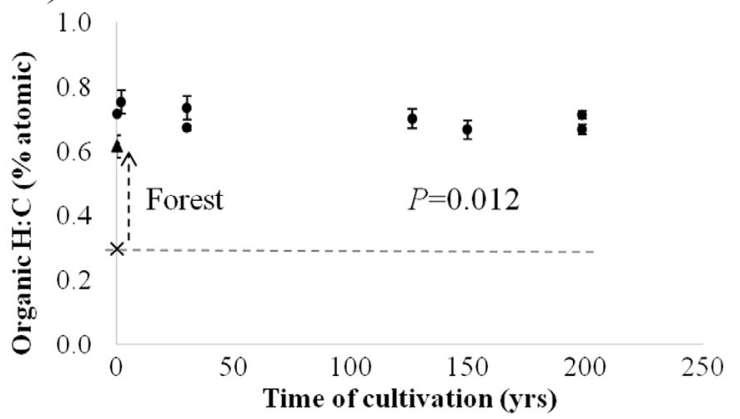

b)

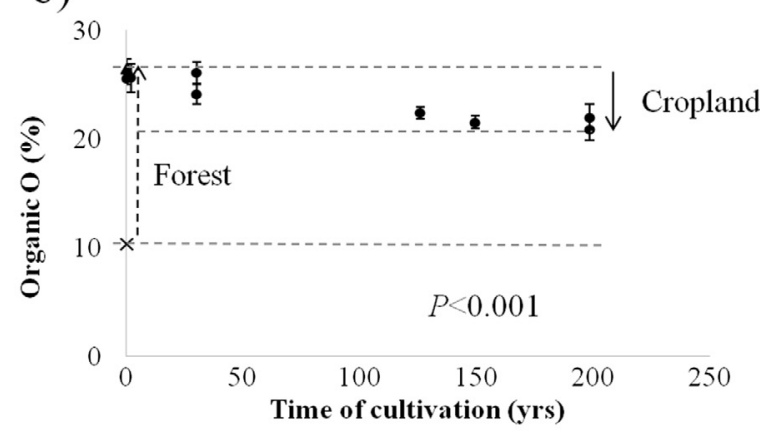

d)

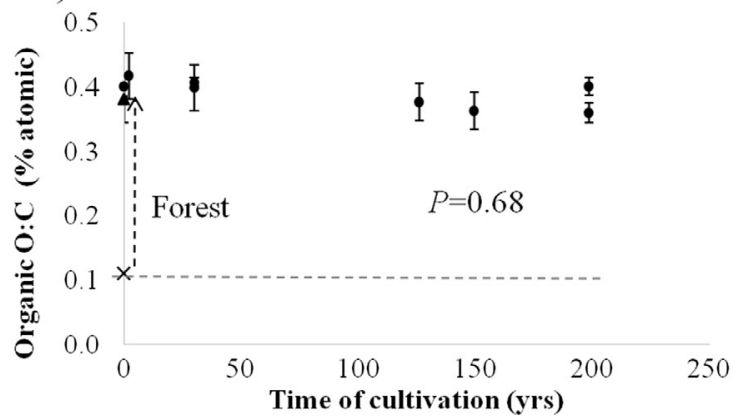

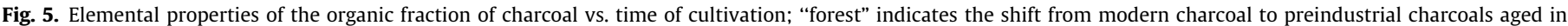

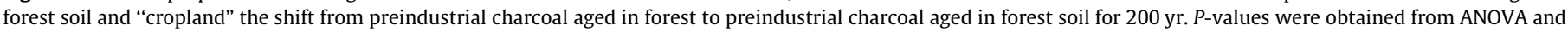
refer to relationship between variable and time of cultivation (excluding charcoal from the active kiln); (a) OC; (b) organic O; (c) organic $\mathrm{H} / \mathrm{C}$; (d) organic $\mathrm{O} / \mathrm{C}$.

ranged from 360 to $416{ }^{\circ} \mathrm{C}$, that of peak 2 from 418 to $430{ }^{\circ} \mathrm{C}$ and that of peak 3 from 493 to $519^{\circ} \mathrm{C}$. We investigated the evolution of both peak temperature and peak area with time of cultivation. The temperature of peak 1 correlated negatively with cultivation time ( $r-0.74$; data not shown), whereas the temperature for peak 2 and 3 was poorly positively correlated with time of cultivation ( $r 0.39$ and $r 0.42$, respectively; data not shown). Like for peak temperature, the area of peak 1 was negatively correlated with time of cultivation ( $r-0.82$; Fig. $7 \mathrm{~b}$ ). The area of peak 2 correlated poorly with time of cultivation $(r 0.28)$, whereas that for peak 3 correlated positively with time of cultivation ( $r$ 0.86; Fig. 7c). From comparison with elemental analysis, the area of peak 1 correlated strongly with organic $O$ content $(r 0.91$; Fig. 8a), whereas the area of peak 3 area correlated negatively with organic $O$ content ( $r-0.91$; Fig. $8 b)$.
In contrast, peak 2 area did not relate to organic $O$ content $(r 0.08)$. We also found a strong negative correlation $(r-0.93)$ between temperature of peak 1 and Ca content (Fig. 8c).

\subsection{Dichromate oxidation}

Charcoal from the modern kiln was quite resistant to dichromate oxidation, as only $6.6 \%$ of OC was oxidized. In contrast, preindustrial charcoals were less resistant. Recovery of OC ranged from $7.32 \%$ to $20.9 \%$ for charcoal aged in forest soil and from $23.9 \%$ to $58.6 \%$ of OC for charcoal aged in agricultural soil. Overall, we found a positive relationship between the susceptibility of charcoal to dichromate oxidation and H/C (Fig. 9). 

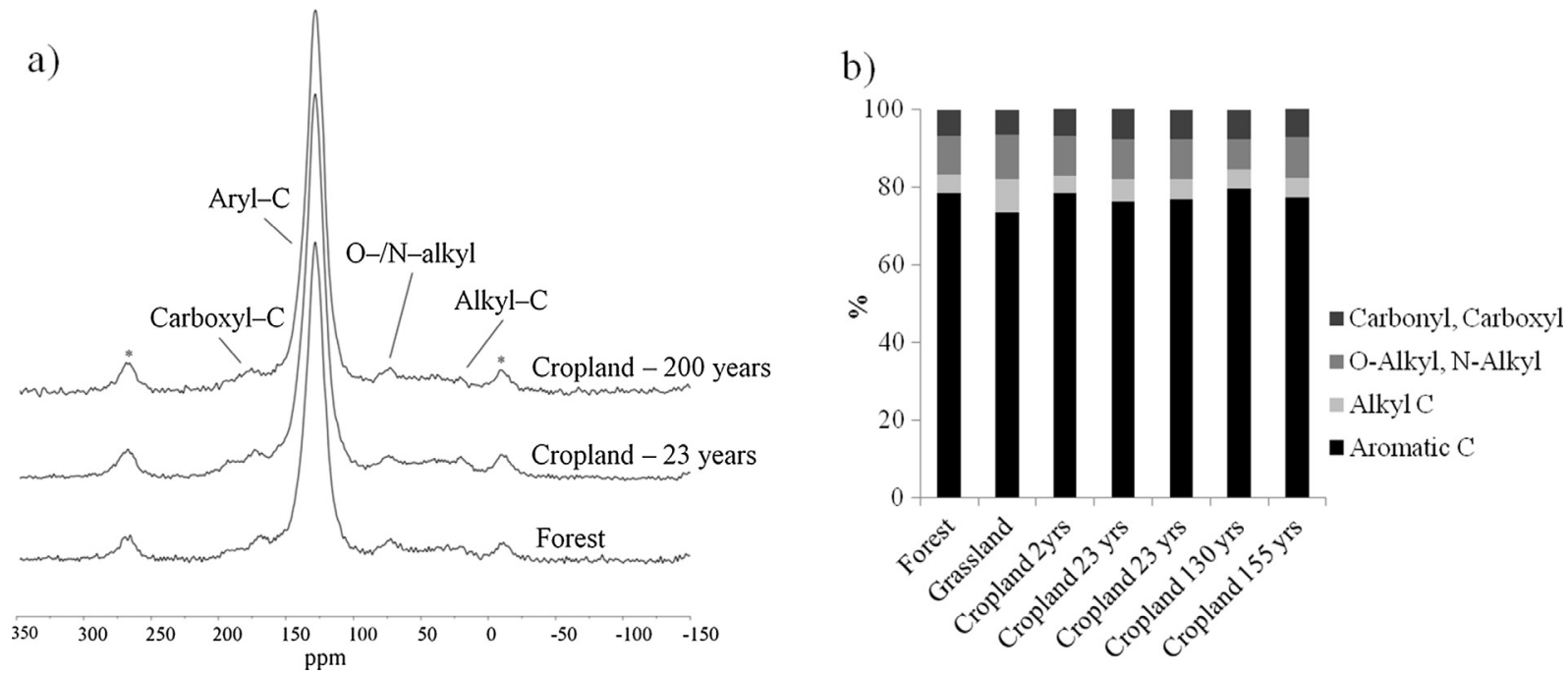

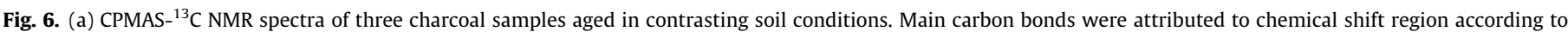

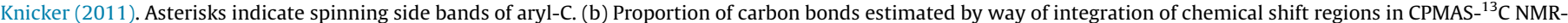
spectra (Knicker, 2011) for charcoal aged under contrasting land uses.

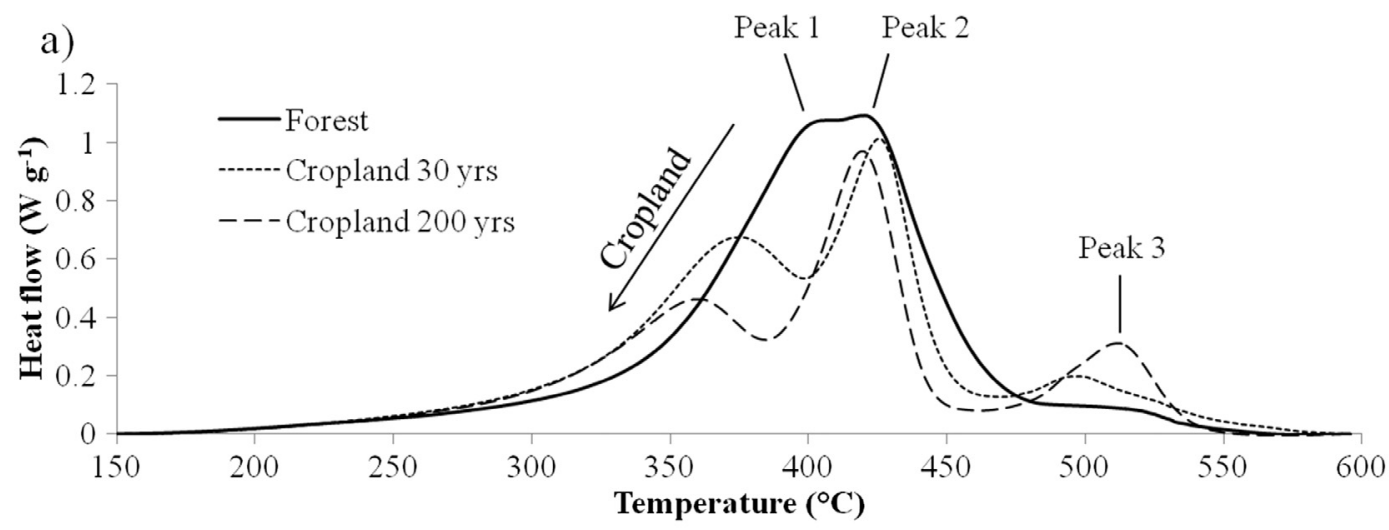

b)

400

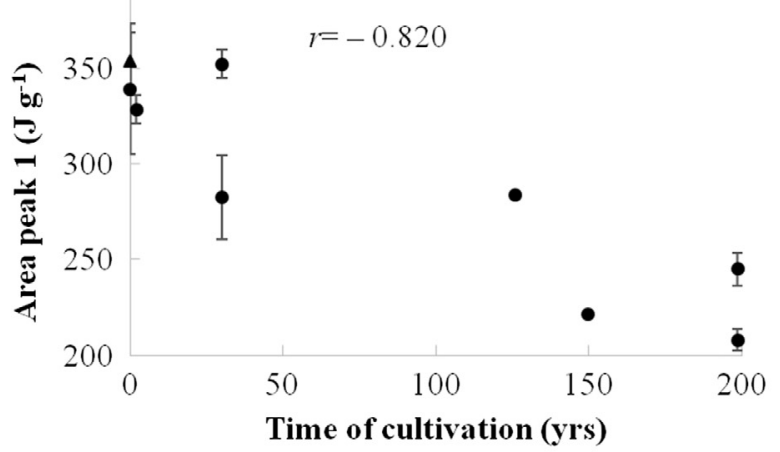

c)

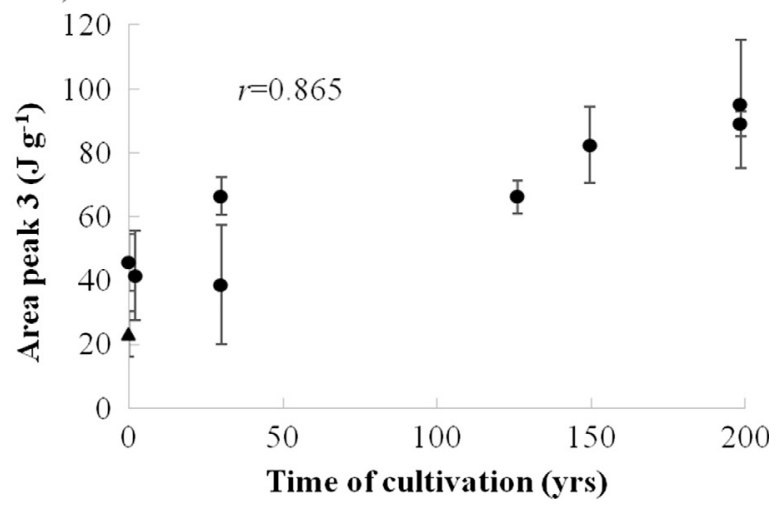

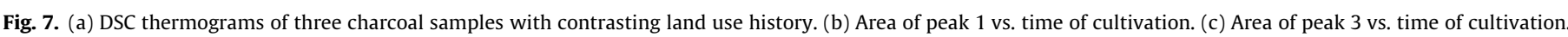

\section{Discussion}

\subsection{Organic composition of charcoal}

During pyrolysis of biomass, elemental $\mathrm{O} / \mathrm{C}$ and $\mathrm{H} / \mathrm{C}$ ratios decrease, related to the transformation of cellulose, hemicellulose and lignin to aromatic clusters, and the loss of gaseous products.
The loss of $\mathrm{O}$ and $\mathrm{H}$ increases gradually with temperature of pyrolysis, according to the degree of aromaticity and aromatic condensation of char (Wiedemeier et al., 2015). Literature data for biochar produced at increasing temperature were plotted in a Van Krevelen diagram to illustrate the transformation (Fig. 4; Keiluweit et al., 2010; Budai et al., 2014). Charcoal extracted from the topsoil of the active kiln has a signature close to that of fresh biochar, with 

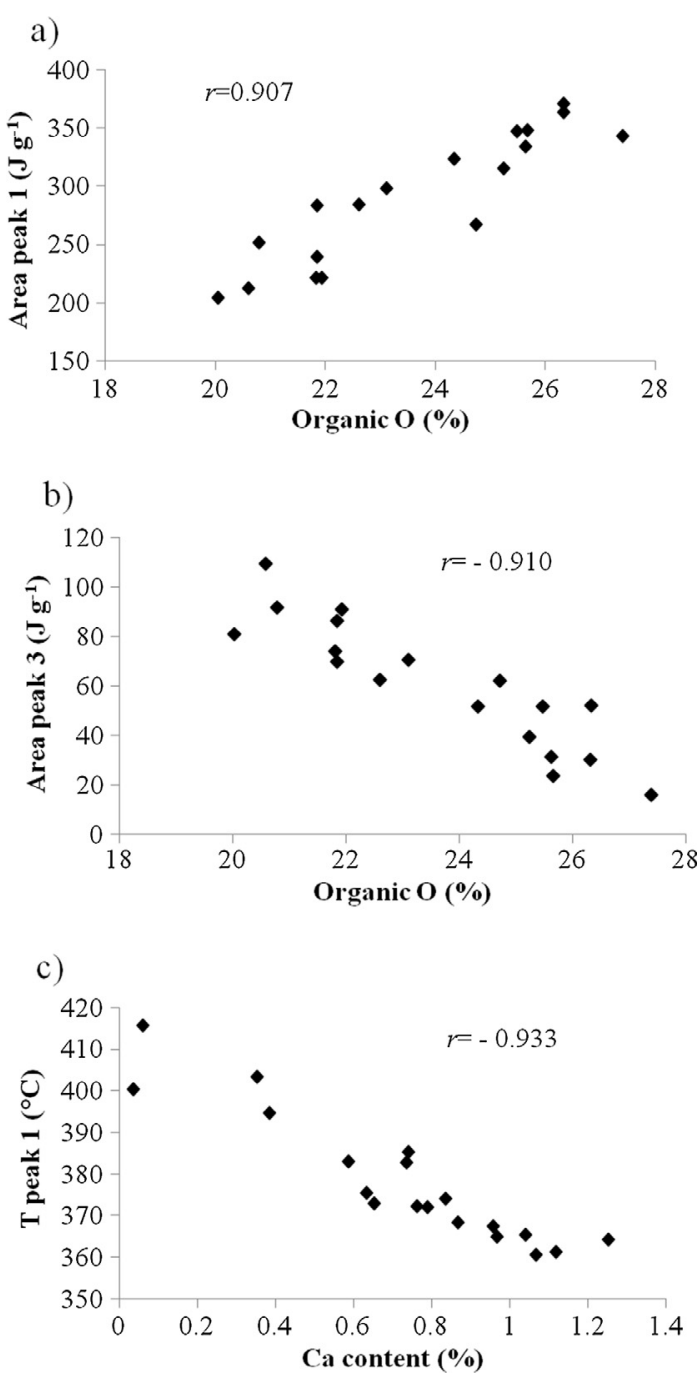

Fig. 8. DSC thermograms from charcoal against (in)organic properties of charcoal; (a) area of peak 1 vs organic 0 content; (b) area of peak 3 vs. organic 0 content; (c) temperature of peak 1 vs. Ca content.

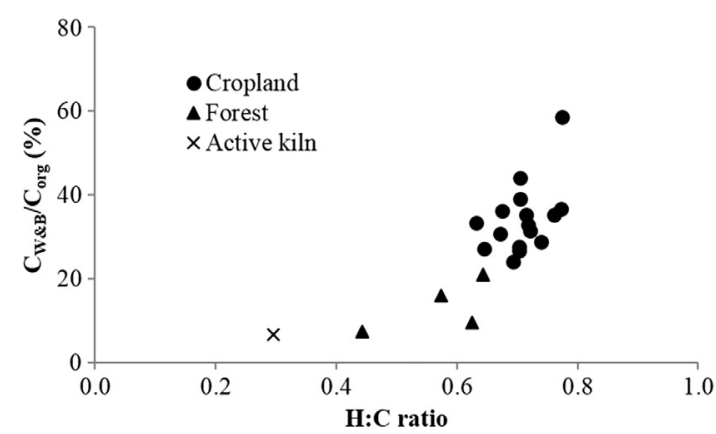

Fig. 9. Fraction of $\mathrm{OC}$ oxidized with dichromate $\left(C_{W \& B} / C_{o r g}\right)$ vs. $H / C$ for organic fraction of charcoal.

slightly larger $\mathrm{O} / \mathrm{C}$ ratio (Fig. 4). The larger $\mathrm{O}$ content might result from an atmosphere not completely depleted in $\mathrm{O}$ during traditional charcoal production with a mound kiln, as conditions of pyrolysis with such a kiln are more difficult to control than laboratory conditions. It might also originate from limited but significant ageing in soil, as charcoal pieces were extracted from soil 6 months after the last pyrolysis.
Compared with fresh biochar, preindustrial charcoal samples have large $\mathrm{H} / \mathrm{C}$ and $\mathrm{O} / \mathrm{C}$ values, ranging respectively from 0.57 to 0.77 and from 0.34 to 0.43 (Fig. 4). Ageing of charcoal in soil results mainly from oxidation starting from the surface and propagating to the core of the particles (Lehmann et al., 2005). Oxidation creates phenol, carbonyl and carboxyl functionalities at the edge of aromatic rings, responsible for the increase in cation exchange capacity of charcoal over time (Cheng et al., 2008a). Accordingly, both O/ $\mathrm{C}$ and $\mathrm{H} / \mathrm{C}$ of charcoal increase through ageing (Cheng et al., 2008a; Calvelo Pereira et al., 2014), somehow counterbalancing the transformations that occur through pyrolysis (aromatization and loss of O-rich functional groups). Weathering is not exactly the reverse process of pyrolysis, however. During pyrolysis, biochar loses on average $2.5 \mathrm{H}$ for one $\mathrm{O}$ when the temperature increases (Keiluweit et al., 2010; Budai et al., 2014; cf. Fig. 4). Through weathering, we evaluated from our data that charcoal gains on average $1.36 \mathrm{H}$ atoms for one $\mathrm{O}$. This may result from hydroxylation and carboxylation at edges of the graphene sheets in charcoal (Lehmann et al., 2005), but also from contamination by organic acids from soil solution (Pignatello et al., 2006) or microbial films in the porosity of charcoal (Lehmann et al., 2011).

Nguyen et al. (2008) estimated from XPS analysis an organic O/ $C$ ratio of ca. 0.35 for fire-derived pyrogenic carbon residue in cultivated soils cleared by slash and burn. In their study, ageing did not affect bulk $\mathrm{O} / \mathrm{C}$ of charcoal over one century. Compared with the value of 0.11 for charcoal from the active kiln, an $\mathrm{O} / \mathrm{C}$ value of 0.35 is very large. This is attributed to the O-rich conditions of production of fire residue contrasting with the O-depleted conditions of pyrolysis. As oxidation of charcoal particles is a preliminary step for microbial decomposition (Hammes and Schmidt, 2009), a smaller O/C value supports a greater stability of charcoal produced by pyrolysis than for fire-derived pyrogenic OM. Nevertheless, after $>150 \mathrm{yr}$, preindustrial charcoal has $\mathrm{O} / \mathrm{C}$ values comparable with that of fire-derived pyrogenic OM (Nguyen et al., 2008). This suggests that the oxidation degree of charcoal increases over time until it reaches a constant value. The slow (a)biotic decomposition of the O-rich fraction of charcoal (Hamer et al., 2004; Kuzyakov et al., 2009), more microbiologically reactive than condensed aromatic rings (Hammes and Schmidt, 2009), might balance oxidation over time and explain why oxidation reaches a steady state after a long time in soil.

In contrast to ageing, there is no clear effect of cultivation on the atomic composition of charcoal. The decrease in organic $C$ content and $\mathrm{O}$ content with time of cultivation (Fig. 5) is related to the relative increase in $\mathrm{Si}, \mathrm{Al}, \mathrm{Fe}$ and $\mathrm{Ca}$ (Fig. 1), supported by the strong negative correlation between $C$ content and the sum of contents of $\mathrm{Si}, \mathrm{Al}$, Fe and Ca quantified from XPS $(r-0.98)$. Despite their high degree of weathering, preindustrial charcoal samples remain mainly aromatic, as shown from FTIR and NMR spectra (Figs. 2 and 6), with a significant fraction of carboxyl-C and carbonyl-C resulting from oxygenation through ageing. From forest to agricultural soil with the longest cultivation time, the FTIR signals from charcoal at ca. $1700 \mathrm{~cm}^{-1}$, corresponding to carboxylic acids, and at ca. $1260 \mathrm{~cm}^{-1}$, corresponding to phenolic acids and $\mathrm{C}-\mathrm{O}$ bonds in $\mathrm{COOH}$ groups (Fig. 2), decrease gradually. This corresponds to the deprotonation of (aromatic) carboxylic acid to carboxylate related to a progressive increase of soil $\mathrm{pH}$ from 3.5-4.0 in acidic forest soil to 7.5-8 after $200 \mathrm{yr}$ liming (Cheng et al., 2008a). Accordingly, the peak at $1375 \mathrm{~cm}^{-1}$ (Fig. 2), attributed to $\mathrm{COO}^{-}$, increases with time of cultivation.

\subsection{Inorganic composition of charcoal and organo-mineral association}

As shown by atomic proportions quantified from XPS (Fig. 1), the contents of $\mathrm{Si}, \mathrm{Al}$ and $\mathrm{Fe}$ in charcoal increase sharply with ageing and, overall, cultivation, which indicates an increase in 


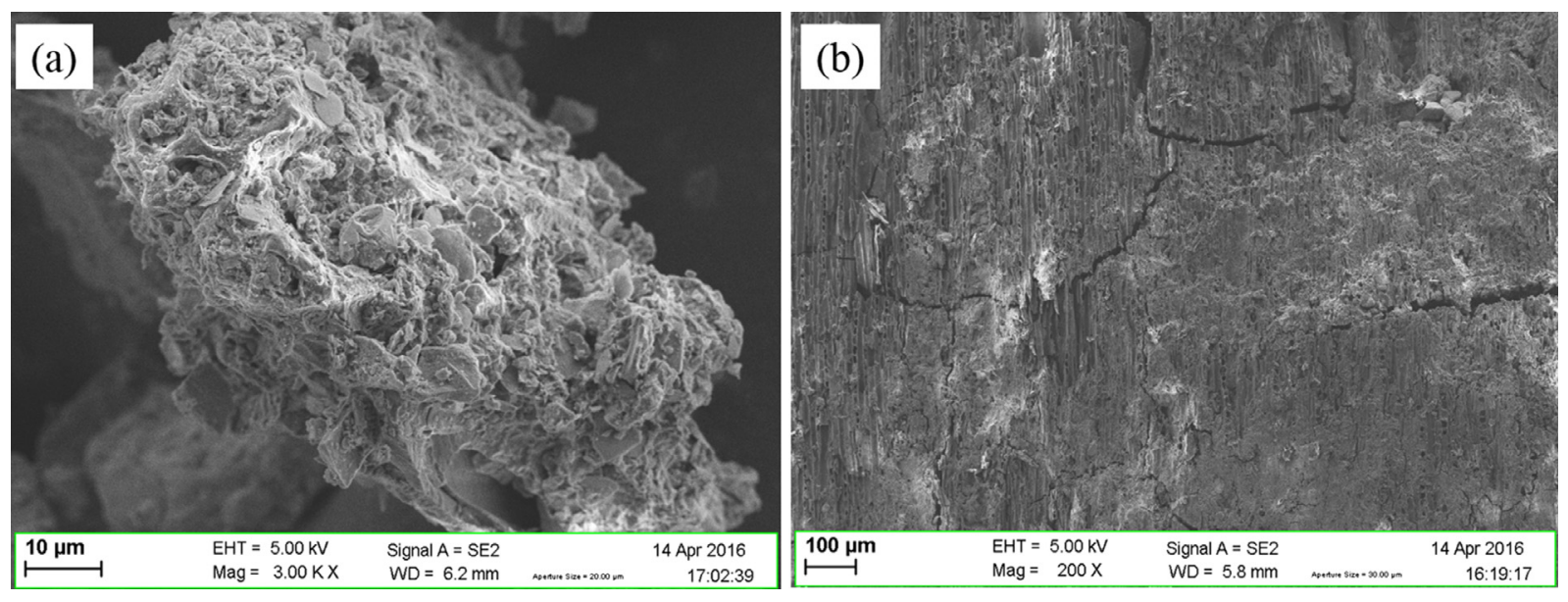

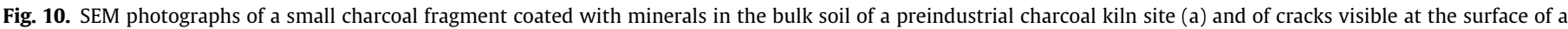
preindustrial charcoal (b).

association with inorganic components of soil. Abundant coating of minerals on the surface of preindustrial charcoal particles, partly occluding the porosity, illustrates the effect (Fig. 10a). The enrichment in $\mathrm{Si}, \mathrm{Al}$ and $\mathrm{Fe}$ follows the increase in $\mathrm{O}$ content measured from XPS (Fig. 1; $r$ 0.96), which indicates that these elements are bonded mainly to $\mathrm{O}$ in soil minerals. We attribute the increase in association with minerals to the combined effect of ageing and liming. Whereas fresh charcoal is highly hydrophobic, ageing mainly consists of the creation of O-rich functional groups (Lehmann et al., 2005; Cheng et al., 2008a) enhancing the polarity of charcoal particles (Criscuoli et al., 2014). Reactivity of organic molecules toward metal cations and mineral surfaces increases with polarity (Kleber et al., 2015). Surface functionalities of aged charcoal are dominated by carboxyl groups (Lehmann et al., 2005), which are known to play a major role in SOM stabilization through organomineral association (Kramer et al., 2012; Kleber et al., 2015). Surfaces of clay minerals such as phyllosilicates and $\mathrm{Fe}$ or $\mathrm{Al}$ (hydr)oxides can adsorb aromatic carboxylic acids by way of both outer- or inner-sphere complexation depending on the adsorbate, mineral type and $\mathrm{pH}$ range (Guan et al., 2006). Therefore, the formation of polar, O-rich functional groups through ageing, mainly carboxyl groups, promotes the association of charcoal with soil minerals.

Over time of cultivation, frequent application of liming amendments by farmers leads to a gradual increase in soil $\mathrm{pH}$ and the consequent deprotonation of carboxylic acids (which have $\mathrm{p} K_{\mathrm{a}}$ between 4 and 5) to carboxylate anions, as inferred from FTIR spectra (Fig. 2). Ionization of organic molecules increases their affinity for mineral surfaces (Kleber et al., 2015). Therefore, deprotonation of carboxylic acids through liming most likely favors mineral association with charcoal over time of cultivation. An increase in inorganic elements in charcoal may result from the coating of minerals at the surface of charcoal particles (Fig. 10a) but also from precipitates in the porosity of charcoal (Fig. 11). Porosity confers to charcoal a large specific surface area, which is an interface for the precipitation of minerals. The energy dispersive $\mathrm{X}$-ray spectroscopy (EDX) signature of foliated structures observed with scanning electron microscopy (SEM) in the charcoal (Fig. 11) corresponds to the atomic composition of 2:1 phyllosilicates, possibly smectite, vermiculite or illite, as significant amounts of Fe, Mg and $\mathrm{K}$ were also identified. This corroborates the $\mathrm{Si} / \mathrm{Al}$ ratio of ca. 2 calculated from XPS results for charcoal subject to cultivation since $200 \mathrm{yr}$, suggesting that inorganic components associated with charcoal are dominated by $2: 1$ phyllosilicates. In contrast, other pores of small diameter are not coated with precipitates (Fig. 11).
This might be related to pore occlusion (Pignatello et al., 2006) causing inaccessibility to solutes transported by water flux, indispensable for neoformation of secondary minerals.

On the other hand, Nguyen et al. (2008) highlighted an increase in the physical breakdown of BC particles over time in cultivated soil, possibly caused by tillage and earthworm activity. An increase in the contact surface accessible to minerals by way of faster fragmentation of charcoal particles in agricultural soil is another factor that might contribute to explain the increase in the content of minerals associated with charcoal over time of cultivation. Large cracks at the surface of charcoal particles illustrate the advanced physical alteration (Fig. 10b).

Whereas charcoal from the active kiln site contains ca. $1 \%$ of $\mathrm{Ca}$, the content decreases through ageing in acidic forest soils (Fig. 1), due to the leaching of "base" cations through natural re-acidification occurring over time after pyrolysis (Hardy et al., 2016). In contrast, Ca content in charcoal increases over time of cultivation in agricultural soils (Fig. 1), with a close correlation with carbonate content (Fig. 3b). This, again, relates to the application of liming amendment (mainly $\mathrm{CaCO}_{3}$ or $\mathrm{Ca}(\mathrm{OH})_{2}$ ) increasing soil $\mathrm{pH}$ and thereby deprotonating carboxylic acids (Fig. 2) that are then saturated with $\mathrm{Ca}^{2+}$. We observed from SEM-EDX a strong signal from $\mathrm{Ca}$ in the C-rich membranes of charcoal (Fig. 11a and b), which supports the idea that Ca is strongly associated with the carbonaceous structure of charcoal. The strong affinity of $\mathrm{Ca}^{2+}$ for carboxylate groups is well known (Kalinichev and Kirkpatrick, 2007) and the consequent high affinity of Ca for aged charcoal was highlighted in earlier studies (Hardy et al., 2016, 2017). Intriguingly, the content of carbonate in soil from which charcoal was extracted is systematically $<0.10 \%$ (data not shown), whereas charcoal from cultivated plots contain up to $5.73 \%$ of carbonate (Fig. 3a). This suggests $\mathrm{CaCO}_{3}$ precipitates preferentially in charcoal due to high specific surface area of charcoal and the high affinity of Ca for carboxyl groups at the surface of charcoal. This result provides further evidence that BC is an important interface for exchange between solid and liquid phases in soil, such as precipitation of minerals.

\subsection{Stability of charcoal}

We investigated the thermal and chemical stability of charcoal with two oxidative methods, DSC and oxidation with dichromate, respectively. In agreement with the shift in atomic composition related to ageing, resistance to dichromate oxidation is less for preindustrial charcoal samples than for freshly produced charcoal 
(a)

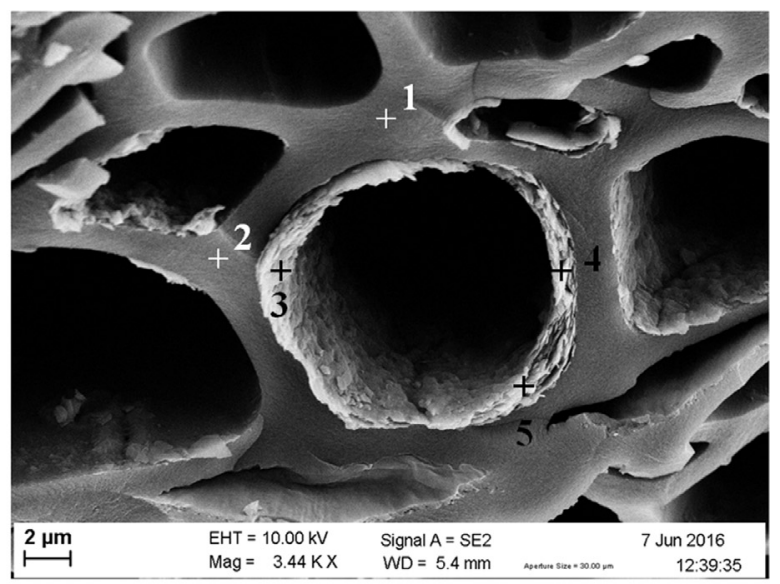

(b)

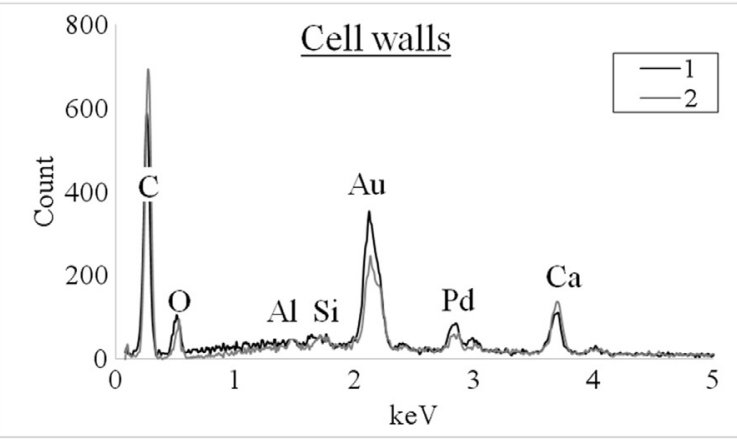

(c)

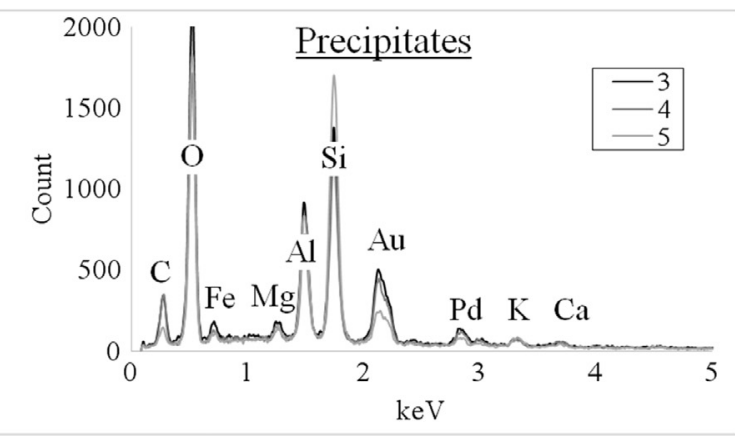

Fig. 11. (a) SEM photograph of inorganic precipitates in a charcoal from a $200 \mathrm{yr}$. cultivated soil (pH 7.85); (b) EDX spectra of cell walls of charcoal; (c), EDX spectra of inorganic precipitates in the porosity of charcoal. Prior to analysis, samples were coated with Au and Pd to limit charge effects, which explains the high concentration of both elements in EDX signatures.

(Fig. 9). Reduced resistance to dichromate oxidation of charcoal exposed to environmental conditions has been reported and was attributed to the physical, chemical or biological weathering of charcoal (Ascough et al., 2011). Accordingly to the findings of Naisse et al. (2013), we found a positive correlation between the susceptibility of charcoal to be oxidized by dichromate and $\mathrm{H} / \mathrm{C}$ (Fig. 9). H/C, which reflects the degree of aromatic condensation of $\mathrm{BC}$ to some extent, is an indicator of the persistence of $\mathrm{BC}$ in the environment (Budai et al., 2013). Our results suggest that, through weathering, the $\mathrm{H} / \mathrm{C}$ ratio of charcoal re-increases, which might correspond to "decondensation" of graphene sheets in the structure of charcoal, possibly caused by physical breakdown coupled with (bio-)chemical oxidation starting at the edges of the graphene sheets and proceeding to their core.

Cultivation had an effect on both chemical and thermal stability of charcoal. The resistance to dichromate oxidation of preindustrial charcoal aged in agricultural soils was lower than that of preindustrial charcoal aged in forest (Fig. 9). This shift in chemical stability was not apparent from FTIR or CPMAS- ${ }^{13} \mathrm{C}$ NMR, which indicates that the link between the molecular composition of $\mathrm{BC}$ and resistance to oxidation is not straightforward. The lower chemical stability of charcoal under cultivation might be explained by a combination of factors. Frequent tillage might deprotect charcoal pieces via disruption of soil aggregates (Kuzyakov et al., 2009), and thereby accelerate the mechanical breakdown of charcoal particles (Nguyen et al., 2008). Liming might also accelerate the breakdown, as the fragmentation of charcoal particles is accelerated by alkaline treatment (Braadbaart et al., 2009). By way of better soil aeration, tillage might promote the abiotic oxidation of charcoal, which is the first step in the weathering of BC (Cheng et al., 2006; Lehmann et al., 2009). Furthermore, the improved nutrient status related to the application of liming and fertilizers favors biological activity in soil and therefore might accelerate the biological decomposition of the most labile fraction of charcoal, particularly by way of co-metabolism with natural SOM (Hamer et al., 2004; Kuzyakov et al., 2009). The decrease in chemical stability of charcoal particles aged in agricultural soil suggests that the particles might decompose more rapidly under cultivation. Nevertheless, Nguyen et al. (2008) proposed that physical protection of $\mathrm{BC}$ by adsorption to minerals and encapsulation in soil aggregates plays an important role in slowing down BC loss from cultivated soil. Association of charcoal with minerals was shown to increase with time of cultivation, which might improve the protection of charcoal against microbial decomposition and therefore balance the lower chemical resistance of charcoal aged in agricultural soil. This assumption is consistent with the high degree of storage of BC in clay rich soils and in soils with high pH (Czimczik and Masiello, 2007; Reisser et al., 2016). Our data do not allow determining which of the two antagonist effects predominates (decrease of chemical resistance vs. increase of association with minerals) for the persistence of charcoal in agricultural soil.

DSC stresses the issue of BC definition and quantification in soil by highlighting the presence of at least three fractions of $C$ with distinct thermal stability in preindustrial charcoal (Fig. 7a), which is not clearly reflected in the organic composition, dominated by aromatic C (Figs. 1 and 6). Over time of cultivation, we reported a clear decrease in both temperature and area of the less thermally stable fraction of charcoal (peak 1) measured with DSC (Fig. 7), with a strong negative correlation between peak temperature and Ca content (Fig. 8c) and a strong positive correlation between peak area and $\mathrm{O}$ content (Fig. 8a). This suggests that, with cultivation, the O-rich fraction of charcoal gets saturated with $\mathrm{Ca}^{2+}$ from liming, which catalyzes its combustion during DSC analysis. A comparable decrease in thermal stability related to the content of $\mathrm{Fe}^{3+}$ and $\mathrm{Al}^{3+}$ was reported for the humic fraction of podzol soil (Schnitzer et al., 1964). Over time of cultivation, the O-rich, less thermally stable fraction of charcoal decreases (Fig. 8b) and the most thermally stable fraction increases accordingly (Fig. 8c). These results can be interpreted in two ways. The decrease of the less thermally stable fraction of charcoal under cropping might result from a faster decomposition of the oxidized fraction of charcoal resulting in a preferential enrichment of the O-poor, more thermally stable fraction. The greater survival over one century of the more condensed fraction of BC in Russian Chernozerms (Hammes et al., 2008), and the greater stability of BC remaining after $20 \mathrm{yr}$ cultivation in soil cleared by forest fire in Kenya (Nguyen et al., 2008) are in agreement with this assumption. However, the smaller content of the O-rich, thermally less stable fraction of charcoal for the long cultivation times and the relative enrichment of the O-poor, thermally stable fraction might also result from the slowdown of the weathering of charcoal related to a better protection of charcoal particles by association with minerals. This is in line with the storage of large amounts of $\mathrm{BC}$ in some 
soils with large clay content and high pH (Czimczik and Masiello, 2007; Reisser et al., 2016). Even though both mechanisms are sound for explaining the relative enrichment of the thermally more stable fraction of charcoal over time of cultivation, they have opposite implications for the persistence of charcoal in cultivated soil. A preferential loss of the O-rich fraction would imply a reduced persistence of charcoal under cultivation, whereas better protection by association with minerals would be synonymous with increased persistence. Therefore, we cannot determine whether cultivation slows down or accelerates the loss of charcoal from soil based on the results of this study.

\section{Conclusion}

For the first time, properties of preindustrial charcoal particles produced by pyrolysis in traditional mound kilns were studied along a chronosequence of land use change from forest to agricultural soil. We investigated the effect of ageing and cultivation on organic and inorganic properties of the charcoal, as well as its thermal and chemical resistance to oxidation. Compared with fresh charcoal, preindustrial charcoal has high $\mathrm{O}$ and $\mathrm{H}$ content due to advanced weathering. Carbon bonds remain, however, dominated by aromatic-C, with a significant fraction of O-rich functional groups such as carboxyl, carbonyl and O-alkyl. Cultivation favors the association charcoal with soil minerals, which results from deprotonation of carboxylic acids to carboxylate ions under liming, enhancing their reactivity toward mineral surfaces. Soil minerals, including 2:1 phyllosilicates and $\mathrm{CaCO}_{3}$, either coat charcoal particles or precipitate inside the charcoal. Thermal stability of preindustrial charcoal explored with DSC revealed the presence of three fractions with distinct thermal resistance in charcoal. The O-rich, less thermally stable fraction decreased over time of cultivation, leading to the relative accumulation of the thermally most stable fraction of charcoal. This might result from the preferential loss of the O-rich fraction due to improved soil conditions under cultivation and the decelerated oxidation of charcoal by association with minerals. Both ageing and cultivation decrease the resistance of charcoal to dichromate oxidation, which was not reflected in the degree of aromaticity. Resistance to chemical oxidation is negatively correlated with $\mathrm{H} / \mathrm{C}$, which is generally considered to mirror the degree of aromatic condensation of char. Our results highlight that land use significantly affects the properties of BC through the modification of soil conditions, which might influence the kinetics of $\mathrm{BC}$ loss from soil. A reliable estimation of the residence time of $B C$ in cultivated soil is key for unveiling the potential contribution of biochar to terrestrial carbon storage.

\section{Acknowledgements}

We are grateful to F.-X. Henrard who took part in sampling, sample preparation and preliminary analyses as a MSc. student. We thank P. Eloy for help with XPS analysis and L. Ryelandt for SEM-EDX images. Funds were provided by the Fonds Spéciaux de Recherche (FSR)-Universite catholique de Louvain. We also thank two anonymous reviewers for constructive comments.

\section{Appendix A. Supplementary material}

Supplementary data associated with this article can be found, in the online version, at http://dx.doi.org/10.1016/j.orggeochem. 2017.02.008.

\section{References}

Abiven, S., Schmidt, M.W.I., Lehmann, J., 2014. Biochar by design. Nature Geoscience 7, 326-327. http://dx.doi.org/10.1038/ngeo2154.

Ascough, P.L., Bird, M.I., Francis, S.M., Thornton, B., Midwood, A.J., Scott, A.C. Apperley, D., 2011. Variability in oxidative degradation of charcoal: influence of production conditions and environmental exposure. Geochimica et Cosmochimica Acta 75, 2361-2378. http://dx.doi.org/10.1016/j. gca.2011.02.002.

Baldock, J.A., Smernik, R.J., 2002. Chemical composition and bioavailability of thermally altered Pinus resinosa (Red pine) wood. Organic Geochemistry 33, 1093-1109. http://dx.doi.org/10.1016/S0146-6380(02)00062-1.

Batjes, N.H., 2016. Harmonized soil property values for broad-scale modelling (WISE30sec) with estimates of global soil carbon stocks. Geoderma 269, 61-68. http://dx.doi.org/10.1016/j.geoderma.2016.01.034.

Biester, H., Knorr, K.H., Schellekens, J., Basler, A., Hermanns, Y.M., 2014. Comparison of different methods to determine the degree of peat decomposition in peat bogs. Biogeosciences 11, 2691-2707. http://dx.doi.org/10.5194/bg-11-26912014.

Bird, M.I., Wynn, J.G., Saiz, G., Wurster, C.M., McBeath, A., 2015. The pyrogenic carbon cycle. Annual Review of Earth and Planetary Science 43, 273-298. http:/ dx.doi.org/10.1146/annurev-earth-060614-105038.

Bohn, U., Neuhäusl, R., Gollub, G., Hettwer, C., Neuhäuslová, Z., Raus, T., Schlüter, H., Weber, H., 2003. Map of the Natural Vegetation of Europe (Scale 1: 2500 000). Landwirtschaftsverlag, Münster.

Braadbaart, F., Poole, I., van Brussel, A.A., 2009. Preservation potential of charcoal in alkaline environments: an experimental approach and implications for the archaeological record. Journal of Archaeological Science 36, 1672-1679. http:// dx.doi.org/10.1016/j.jas.2009.03.006.

Bryson, C.E., 1987. Surface potential control in XPS. Surface Science 189-190, 50-58. http://dx.doi.org/10.1016/S0039-6028(87)80414-4.

Budai, A., Wang, L., Gronli, M., Strand, L.T., Antal, M.J., Abiven, S., Dieguez-Alonso, A., Anca-Couce, A., Rasse, D.P., 2014. Surface properties and chemical composition of corncob and miscanthus biochars: effects of production temperature and method. Journal of Agricultural and Food Chemistry 62, 3791-3799. http://dx. doi.org/10.1021/jf501139f.

Budai, A., Zimmerman, A.R., Cowie, A.L., Webber, J.B.W., Singh, B.P., Glaser, B., Masiello, C.A., Andersson, D., Shields, F., Lehmann, J., Camps Arbestain, M., Williams, M., Sohi, S., Joseph, S., 2013. Biochar Carbon Stability Test Method: An Assessment of Methods To Determine Biochar Carbon Stability [WWW Document]. International Biochar Initiative. <www.biochar-international.org/ sites/default/files/IBI_Report_Biochar_Stability_Test_Method_Final.pdf $>$.

Calvelo Pereira, R., Camps Arbestain, M., Kaal, J., Vazquez Sueiro, M., Sevilla, M., Hindmarsh, J., 2014. Detailed carbon chemistry in charcoals from pre-European Māori gardens of New Zealand as a tool for understanding biochar stability in soils. European Journal of Soil Science 65, 83-95. http://dx.doi.org/10.1111/ ejss.12096.

Cheng, C.-H., Lehmann, J., Engelhard, M.H., 2008a. Natural oxidation of black carbon in soils: changes in molecular form and surface charge along a climosequence. Geochimica et Cosmochimica Acta 72, 1598-1610. http://dx.doi.org/10.1016/j. gca.2008.01.010.

Cheng, C.-H., Lehmann, J., Thies, J.E., Burton, S.D., 2008b. Stability of black carbon in soils across a climatic gradient. Journal of Geophysical Research 113, G02027. http://dx.doi.org/10.1029/2007JG000642.

Cheng, C.-H., Lehmann, J., Thies, J.E., Burton, S.D., Engelhard, M.H., 2006. Oxidation of black carbon by biotic and abiotic processes. Organic Geochemistry 37, 14771488. http://dx.doi.org/10.1016/j.orggeochem.2006.06.022.

Criscuoli, I., Alberti, G., Baronti, S., Favilli, F., Martinez, C., Calzolari, C., Pusceddu, E., Rumpel, C., Viola, R., Miglietta, F., 2014. Carbon sequestration and fertility after centennial time scale incorporation of charcoal into soil. PLoS ONE 9, 1-11. http://dx.doi.org/10.1371/journal.pone.0091114.

Czimczik, C.I., Masiello, C.A., 2007. Controls on black carbon storage in soils. Global Biogeochemical Cycles 21, GB3005. http://dx.doi.org/10.1029/2006GB002798.

Danley, R.L., 2003. New heat flux DSC measurement technique. Thermochimica Acta 395 (1-2), 201-208.

Day, P.R., 1965. Particle fractionation and particle size analysis. In: Black, C.A. (Ed.) Methods of Soil Analysis. Part 1. Physical and Mineralogical Properties, Including Statistics of Measurement and Sampling. American Society of Agronomy, Soil Science Society of America, Madison, WI, USA, pp. 545-567.

Evrard, R., 1956. Forges Anciennes. Editions Solédi, Liège, Belgium.

Glaser, B., Birk, J.J., 2012. State of the scientific knowledge on properties and genesis of Anthropogenic Dark Earths in Central Amazonia (terra preta de Índio). Geochimica et Cosmochimica Acta 82, 39-51. http://dx.doi.org/10.1016/j. gca.2010.11.029.

Goidts, E., van Wesemael, B., 2007. Regional assessment of soil organic carbon changes under agriculture in Southern Belgium (1955-2005). Geoderma 141, 341-354. http://dx.doi.org/10.1016/j.geoderma.2007.06.013.

Guan, X.H., Chen, G.H., Shang, C., 2006. Combining kinetic investigation with surface spectroscopic examination to study the role of aromatic carboxyl groups in NOM adsorption by aluminum hydroxide. Journal of Colloid Interface Science 301, 419-427. http://dx.doi.org/10.1016/j.jcis.2006.05.031.

Guo, L.B., Gifford, R.M., 2002. Soil carbon stocks and land use change: a meta analysis. Global Change Biology 8, 345-360. http://dx.doi.org/10.1046/j.13541013.2002.00486.x. 
Hamer, U., Marschner, B., Brodowski, S., Amelung, W., 2004. Interactive priming of black carbon and glucose mineralisation. Organic Geochemistry 35, 823-830. http://dx.doi.org/10.1016/j.orggeochem.2004.03.003.

Hammes, K., Schmidt, M.W.I., 2009. Changes of biochar in soil. In: Lehmann, J., Joseph, S. (Eds.), Biochar for Environmental Management: Science and Technology. Earthscan, London, pp. 169-181.

Hammes, K., Torn, M.S., Lapenas, A.G., Schmidt, M.W.I., 2008. Centennial black carbon turnover observed in a Russian steppe soil. Biogeosciences 5, 13391350. http://dx.doi.org/10.5194/bg-5-1339-2008.

Hardy, B., Cornelis, J.-T., Houben, D., Lambert, R., Dufey, J.E., 2016. The effect of preindustrial charcoal kilns on chemical properties of forest soil of Wallonia, Belgium. European Journal of Soil Science 67, 206-216. http://dx.doi.org/ $10.1111 /$ ejss. 12324.

Hardy, B., Cornelis, J.-T., Houben, D., Leifeld, J., Lambert, R., Dufey, J., 2017 Evaluation of the long-term effect of biochar on properties of temperate agricultural soil at pre-industrial charcoal kiln sites in Wallonia, Belgium. European Journal of Soil Science 68, 80-89. http://dx.doi.org/10.1111/ ejss.12395.

Hardy, B., Dufey, J., 2012. Estimation des besoins en charbon de bois et en superficie forestière pour la sidérurgie wallonne préindustrielle (1750-1830) Deuxième partie: les besoins en superficie forestière. Revue Forestière Française, 799-806.

Hockaday, W.C., Grannas, A.M., Kim, S., Hatcher, P.G., 2007. The transformation and mobility of charcoal in a fire-impacted watershed. Geochimica et Cosmochimica Acta 71, 3432-3445. http://dx.doi.org/10.1016/j.gca.2007.02.023.

Jaffé, R., Ding, Y., Niggemann, J., Vähätalo, A.V., Stubbins, A., Spencer, R.G.M., Campbell, J., Dittmar, T., 2013. Global charcoal mobilization from soils via dissolution and riverine transport to the oceans. Science 340, 345-347. http:/ dx.doi.org/10.1126/science.1231476.

Joseph, S.D., Camps-Arbestain, M., Lin, Y., Munroe, P., Chia, C.H., Hook, J., van Zwieten, L., Kimber, S., Cowie, A., Singh, B.P., Lehmann, J., Foidl, N., Smernik, R.J., Amonette, J.E., 2010. An investigation into the reactions of biochar in soil. Australian Journal of Soil Research 48, 501-515. http://dx.doi.org/10.1071/ SR10009.

Kalinichev, A.G., Kirkpatrick, R.J., 2007. Molecular dynamics simulation of cationic complexation with natural organic matter. European Journal of Soil Science 58 909-917. http://dx.doi.org/10.1111/j.1365-2389.2007.00929.x.

Keiluweit, M., Nico, P.S., Johnson, M.G., Kleber, M., 2010. Dynamic molecular structure of plant biomass-derived black carbon (biochar). Environmental Science \& Technology 44, 1247-1253. http://dx.doi.org/10.1021/es9031419.

Kerré, B., Bravo, C.T., Leifeld, J., Cornelissen, G., Smolders, E., 2016. Historical soil amendment with charcoal increases sequestration of non-charcoal carbon: a comparison among methods of black carbon quantification. European Journal of Soil Science 67, 324-331. http://dx.doi.org/10.1111/ejss.12338.

Kervyn, T., Jacquemin, F., Branquart, E., Delahaye, L., Dufrêne, M., Claessens, H. 2014. Les forêts anciennes en Wallonie. 2ème partie: Cartographie. Forêt Wallonne 133, 38-52.

Kleber, M., Eusterhues, K., Keiluweit, M., Mikutta, C., Mikutta, R., Nico, P.S., 2015. Mineral-organic associations: formation, properties, and relevance in soil environments. Advances in Agronomy 130, 1-140. http://dx.doi.org/10.1016/ bs.agron.2014.10.005.

Knicker, H., 2011. Solid state CPMAS ${ }^{13} \mathrm{C}$ and ${ }^{15} \mathrm{~N}$ NMR spectroscopy in organic geochemistry and how spin dynamics can either aggravate or improve spectra interpretation. Organic Geochemistry 42, 867-890. http://dx.doi.org/10.1016/j. orggeochem.2011.06.019.

Kramer, M.G., Sanderman, J., Chadwick, O.A., Chorover, J., Vitousek, P.M., 2012. Long-term carbon storage through retention of dissolved aromatic acids by reactive particles in soil. Global Change Biology 18, 2594-2605. http://dx.doi. org/10.1111/j.1365-2486.2012.02681.x.

Kuzyakov, Y., Subbotina, I., Chen, H., Bogomolova, I., Xu, X., 2009. Black carbon decomposition and incorporation into soil microbial biomass estimated by ${ }^{14} \mathrm{C}$ labeling. Soil Biology and Biochemistry 41, 210-219. http://dx.doi.org/10.1016/ j.soilbio.2008.10.016

Lehmann, J., 2007. A handful of carbon. Nature 447, 10-11.

Lehmann, J., Czimczik, C., Laird, D., Sohi, S., 2009. Stability of biochar in soil. In: Lehmann, J., Joseph, S. (Eds.), Biochar for Environmental Management: Science and Technology. Earthscan, London, pp. 183-205.

Lehmann, J., Liang, B., Solomon, D., Lerotic, M., Luizão, F., Kinyangi, J., Schäfer, T. Wirick, S., Jacobsen, C., 2005. Near-edge X-ray absorption fine structure (NEXAFS) spectroscopy for mapping nano-scale distribution of organic carbon forms in soil: application to black carbon particles. Global Biogeochemical Cycles 19, GB1013. http://dx.doi.org/10.1029/2004GB002435.

Lehmann, J., Rillig, M.C., Thies, J.E., Masiello, C.A., Hockaday, W.C., Crowley, D., 2011 Biochar effects on soil biota - a review. Soil Biology and Biochemistry 43, 1812 1836. http://dx.doi.org/10.1016/j.soilbio.2011.04.022.
Lehmann, J., Solomon, D., 2010. Organic carbon chemistry in soils observed by synchrotron-based spectroscopy. Developments in Soil Science 34, 289-312. http://dx.doi.org/10.1016/S0166-2481(10)34010-4.

Leifeld, J., 2007. Thermal stability of black carbon characterised by oxidative differential scanning calorimetry. Organic Geochemistry 38, 112-127. http://dx. doi.org/10.1016/j.orggeochem.2006.08.004.

Masiello, C.A., 2004. New directions in black carbon organic geochemistry. Marine Chemistry 92, 201-213. http://dx.doi.org/10.1016/j.marchem.2004.06.043.

Naisse, C., Alexis, M., Plante, A., Wiedner, K., Glaser, B., Pozzi, A., Carcaillet, C., Criscuoli, I., Rumpel, C., 2013. Can biochar and hydrochar stability be assessed with chemical methods? Organic Geochemistry 60, 40-44. http://dx.doi.org/ 10.1016/j.orggeochem.2013.04.011.

Nguyen, B.T., Lehmann, J., 2009. Black carbon decomposition under varying water regimes. Organic Geochemistry 40, 846-853. http://dx.doi.org/10.1016/j. orggeochem.2009.05.004.

Nguyen, B.T., Lehmann, J., Hockaday, W.C., Joseph, S., Masiello, C.A., 2010. Temperature sensitivity of black carbon decomposition and oxidation. Environmental \& Science Technology 44, 3324-3331. http://dx.doi.org/ 10.1021/es903016y.

Nguyen, B.T., Lehmann, J., Kinyangi, J., Smernik, R., Riha, S.J., Engelhard, M.H., 2008. Long-term black carbon dynamics in cultivated soil. Biogeochemistry 89, 295308. http://dx.doi.org/10.1007/s10533-008-9220-9.

Nye, P.H., Greenland, D.J., 1964. Changes in the soil after clearing tropical forest. Plant and Soil 21, 101-112.

Pignatello, J.J., Kwon, S., Lu, Y., 2006. Effect of natural organic substances on the surface and adsorptive properties of environmental black carbon (char): attenuation of surface activity by humic and fulvic acids. Environmental Science \& Technology 40, 7757-7763.

Reimer, P., 2013. IntCal13 and Marine13 radiocarbon age calibration curves 050,000 years cal BP. Radiocarbon 55, 1869-1887. http://dx.doi.org/10.2458/ azu_js_rc.55.16947.

Reisser, M., Purves, R.S., Schmidt, M.W.I., Abiven, S., 2016. Pyrogenic carbon in soils: a literature-based inventory and a global estimation of its content in soil organic carbon and stocks. Frontiers in Earth Science 4, 1-14. http://dx.doi.org/ 10.3389/feart.2016.00080.

Rumpel, C., Alexis, M., Chabbi, A., Chaplot, V., Rasse, D.P., Valentin, C., Mariotti, A., 2006. Black carbon contribution to soil organic matter composition in tropical sloping land under slash and burn agriculture. Geoderma 130, 35-46. http://dx. doi.org/10.1016/j.geoderma.2005.01.007.

Schmidt, M.W.I., 2004. Biogeochemistry: carbon budget in the black. Nature 427 305-307. http://dx.doi.org/10.1038/427305a.

Schmidt, M.W.I., Noack, A.G., 2000. Black carbon in soils and sediments: analysis, distribution, implications, and current challenges. Global Biogeochemical Cycles 14, 777-793. http://dx.doi.org/10.1029/1999GB001208.

Schnitzer, M., Turner, R.C., Hoffman, I., 1964. A thermo-gravimetric study of organic matter of representative Canadian podzol soils. Canadian Journal of Soil Science 44, 7-13.

Schweingruber, F.H., 1990. Microscopic Wood Anatomy: Structural Variability of Stems and Twigs in Recent and Subfossil Woods from Central Europe. Eidgenössische Forschungsanstalt WSL, Birmensdorf, Switzerland.

Sherrod, L.A., Dunn, G., Peterson, G.A., Kolberg, R.L., 2002. Inorganic carbon analysis by modified pressure-calcimeter method. Soil Society of America Journal 66, 299-305.

Shirley, D.A., 1972. High-resolution X-ray photoemission spectrum of the valence bands of gold. Physical Reviews B 5, 4709-4714. http://dx.doi.org/10.1103/ PhysRevB.5.4709.

Solomon, D., Lehmann, J., Kinyangi, J., Amelung, W., Lobe, I., Pell, A., Riha, S., Ngoze, S., Verchot, L., Mbugua, D., Skjemstad, J., Schäfer, T., 2007. Long-term impacts of anthropogenic perturbations on dynamics and speciation of organic carbon in tropical forest and subtropical grassland ecosystems. Global Change Biology 13, 511-530. http://dx.doi.org/10.1111/j.1365-2486.2006.01304.x.

Walkley, A., 1947. A critical examination of a rapid method for determining organic carbon in soils - effect of variations in digestion conditions and of inorganic soil constituents. Soil Science 63, 251-264.

Wengel, M., Kothe, E., Schmidt, C.M., Heide, K., Gleixner, G., 2006. Degradation of organic matter from black shales and charcoal by the wood-rotting fungus Schizophyllum commune and release of DOC and heavy metals in the aqueous phase. Science of the Total Environment 367, 383-393.

Wiedemeier, D.B., Abiven, S., Hockaday, W.C., Keiluweit, M., Kleber, M., Masiello, C. A., McBeath, A.V., Nico, P.S., Pyle, L.A., Schneider, M.P.W., Smernik, R.J., Wiesenberg, G.L.B., Schmidt, M.W.I., 2015. Aromaticity and degree of aromatic condensation of char. Organic Geochemistry 78, 135-143. http://dx.doi.org/ 10.1016/j.orggeochem.2014.10.002. 